\title{
Manufacturing technique and social identity: three cases of 'manufacture-by-wear' technique
}

\author{
MONICA MĂRGĂRIT ${ }^{1}$, PAVEL MIREA ${ }^{2}$, ADRIAN BĂLĂȘESCU ${ }^{3}$ \\ ${ }^{1}$ Valahia University of Târgoviște, Humanities Faculty, str. Lt. Stancu Ion, nr. 35, Târgoviște, Romania \\ ${ }^{2}$ Teleorman County Museum, str. 1848, nr. 1, Alexandria, Romania \\ 3“"Vasile Pârvan" Institute of Archaeology, Romanian Academy, str. Henri Coandă, nr. 11, București, Romania
}

(Received 8 June 2017; Revised 13 April 2018; Accepted 4 May 2018)

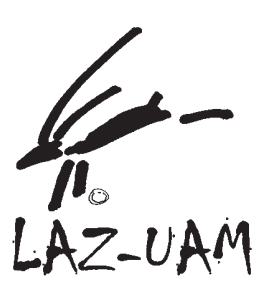

ABSTRACT: This paper focuses on the identification of changes in the processing of osseous materials in the southeast European Neolithic, beginning with three types of production by manufacture wear technique typical for the region: bipartition by abrasion, segmentation with fibre and perforation by wear technique. The processing of osseous materials is strongly conditioned by their natural anatomic shapes which is why only a restricted range of possible transformation variables, with minimum changes through time, would be expected. However, numerous specialists invoke the cultural value conferred by the community as the preeminent element in the selection of raw material more than the limitations of the raw material form. Therefore, there are some examples in which there was little change in raw materials selection across long periods of time, although there was variation in animal species availability. Consequently, the study of the three types of 'manufacture-by-wear' technique becomes more interesting. These techniques are not present in all prehistoric times in this region. Some of these techniques appear on worked osseous materials in Romania and neighbouring areas at the beginning of the Neolithic and disappear just as suddenly (bipartition by abrasion) or appear only sporadically (perforation and segmentation with fibre) by the Early Chalcolithic. Based on experimental reconstructions of the three processing techniques and comparing them with archaeological assemblages, our study aims to register all the relevant variables (technological gestures, time required for each operation, tools used etc.), and evaluate if they represented a real innovation in the way which the osseous materials were processed.

KEYWORDS: SOUTHEASTERN EUROPE, ROMANIA, NEOLITHIC, OSSEOUS EXPLOITATION, TECHNOLOGICAL CHOICES, CULTURAL TRADITIONS

RESUMEN: Este trabajo se centra en la identificación de cambios operados en el procesado de materiales óseos en el Neolítico del sudeste europeo a partir de tres tipos de producción de manufacturas por la técnica de desgaste que son típicas de la región: bipartición por abrasión, segmentación con fibra y perforación por técnica de erosión. El procesado de las materias óseas viene muy condicionado por sus formas anatómicas naturales, razón por la cual solo un rango restringido de variables de transformación con cambios mínimos a través del tiempo es esperable. No obstante, numerosos especialistas invocan al valor cultural conferido por la comunidad como el elemento clave en la selección de materias primas más que estas limitaciones aludidas sobre la forma de la materia prima. Por ello, existen algunos ejemplos en donde ha habido poco cambio a lo largo del tiempo en la selección de las materias primas a pesar de haber habido variabilidad en la disponibilidad de especies animales. Como resultado de esto el estudio de los tres tipos de técnica de (manufacturado por desgaste) se torna más interesante. Estas técnicas no están presentes en la región en todo momento. Algunas de ellas aparecen en material óseo trabajado en Rumania y zonas adyacentes a principios del Neolítico pero desaparecen igual de rápido (bipartición por abrasión) o solo lo hacen de forma esporádica a principios del Calcolí- 
tico (perforación y segmentación con fibra). Basándonos en análisis experimentales de las tres técnicas de procesado y comparando ello con los conjuntos arqueológicos, nuestro estudio pretende incorporar todas las variables relevantes (gestos tecnológicos, tiempo requerido para cada operación, herramientas utilizadas, etc.) y evaluar si estas representan una innovación auténtica en el modo en que fueron procesados los materiales óseos.

PALABRAS CLAVE: EUROPA SUDORIENTAL, RUMANIA, NEOLÍTICO, APROVECHAMIENTO DEL HUESO, OPCIONES TECNOLÓGICAS, TRADICIONES CULTURALES

\section{INTRODUCTION}

The importance of cultural factors in the technical choices of prehistoric communities has already been emphasized by numerous specialists (e.g., Dobres, 2000, 2010; Luik \& Maaldre, 2007; Stark et al., 2008; Choyke, 2009, 2013, 2014; Choyke \& Daroczi-Szabo, 2010; etc.). As Lemonnier (1992) observed, technology is not only one means by which human communities act upon their physical environment, but also the act of manufacturing something is a social productions in itself. It concerns the active involvement of people in the creation of their material world in a continuous process, in which "ancient technologies materialized prevailing worldviews, social values and cultural attitudes about how to live in and act on the world" (Dobres, 2010: 106). These conditionings, Bourdieu (1977) called them habitus - a form of social pressure to maintain the identity of the community, direct all the stages of the chaine opératoire, from the selection strategies for raw materials to the choice of technological transformation schemes and the stages of utilization, curation and recycling.

Thus, technical choice in bone-based technologies underwent only insignificant modifications over long periods of time, despite changes in animal species availability (e.g., Choyke et al., 2004; Luik, 2011). The innovations seem to reflect 'social quakes' within the communities, generating cracks and discontinuities, many of them identifiable at the archaeological level (but they also represent a kind of agency by which people at the time could express certain changes in their social identities). This opinion is widely shared by specialists (e.g., Creswell, 1994; Choyke, 2005; Roux, 2010, 2013). The agency of objects and their manufacture is very well described by Wobst (1999: 126): "each new tool modifies the social field. It reshapes the template for what is thought or known to be practical. It modifies the reference points".

Starting with these opinions, the purpose of this paper is to explore and identify the transformations of the osseous industry throughout the North-Danubian Neolithic, with a particular focus on three types of the 'manufacture-by-wear' technique: bipartition by abrasion, segmentation with fibre and perforation by wear technique. The goal is to understand the factors that defined the use of the material manufacture-by-wear techniques as opposed to other possible techniques for processing artefacts. We will also try to identify, if possible, the moment these manufacture-by-wear techniques appeared and were abandoned in the discussed region. Following this path, we wish to answer the question: can these 'manufacture-by-wear' techniques be used as indicators of particular cultural/social phenomena in the past? When these new approaches are developed or appear in the region (with the beginning of the Early Neolithic), they are accompanied by other markers of socio-economical change e.g., small agricultural farms, rituals centred upon the female symbol and Spondylus adornments of Mediterranean origin (Perlès, 2010) and therefore represent changes in manufacturing traditions even at the conservative household level.

\section{TERMINOLOGY AND METHODOLOGY}

\section{Definitions}

The method of bipartition by abrasion was first identified by Poplin (1974) and detailed in other papers. Its presence is attested widely across the European continent (Sénépart, 2004; Sidéra, 2004; Choyke, 2007; Vitezović, 2013a) (see Table 1). 


\begin{tabular}{|c|c|c|c|c|c|c|c|}
\hline Wear technique & Region & Culture/ Period & Dating (BC) & Sites & Bone & Species & References \\
\hline \multirow{24}{*}{$\begin{array}{l}\text { Bipartition by } \\
\text { abrasion }\end{array}$} & \multirow[t]{3}{*}{ Spain } & \multirow[t]{3}{*}{ Neolithic I } & \multirow[t]{3}{*}{ c. $5600-4500$} & Cova de l'Or & Metapodial & Ruminant & \multirow{2}{*}{$\begin{array}{l}\text { Marti Oliver, 1993; } \\
\text { Pascual Benito, } 2016\end{array}$} \\
\hline & & & & Cova de la Sarsa & Metapodial & Ruminant & \\
\hline & & & & \begin{tabular}{|l|} 
La Draga \\
\end{tabular} & Metapodial & Ruminant & \begin{tabular}{|l|} 
Bosch et al., 2000; \\
Pascual Benito, 2016 \\
\end{tabular} \\
\hline & \multirow[t]{9}{*}{ France } & \multirow[t]{5}{*}{ Rubané } & \multirow[t]{5}{*}{ c. $5500-4700$} & Cuiry-lès-Chaudardes & Metapodial & Ruminant & Sidéra, 2012 \\
\hline & & & & Berry-au-Bac & Metapodial & Ruminant & Sidéra, 1995 \\
\hline & & & & \begin{tabular}{|l|} 
Bucy-le-Long \\
"La Fosselle" \\
\end{tabular} & Metapodial & Ruminant & Sidéra, 2008 \\
\hline & & & & Etigny "Le Brassot-Est" & Metapodial & Ruminant & \\
\hline & & & & $\begin{array}{l}\text { Missy-sur-Aisne } \\
\text { "Le Culot" }\end{array}$ & Metapodial & Ruminant & \\
\hline & & \multirow[t]{3}{*}{ VSG } & \multirow[t]{3}{*}{ c. $4950-4650$} & Villeneuve-la-Guyard & Metapodial & Ruminant & \\
\hline & & & & $\begin{array}{l}\text { Jablines "La Pente de } \\
\text { Croupeton" }\end{array}$ & Metapodial & Ruminant & \\
\hline & & & & Mareuil-lès-Meaux & Metapodial & Ruminant & \\
\hline & & Chasséen & c. $4200-3500$ & Fontbrégoua & Metapodial & Ruminant & Sénépart, 1984, 2004 \\
\hline & Italy & SMP & c. $4950-4050$ & Arene Candide & Metapodial & Ruminant & Maggi et al., 1997 \\
\hline & \multirow[t]{2}{*}{ Switzerland } & \multirow[t]{2}{*}{ Cortaillod } & \multirow{2}{*}{ c. $3900-3500$} & Auvernier-Port & Metapodial & Ruminant & Murray, 1979 \\
\hline & & & & Muntelier/Fischergässli & Metapodial & Ruminant & Sidéra, 2000a \\
\hline & Austria & LBK & c. $5500-4500$ & Asparn/Zaya-Schletz & Metapodial & Ruminant & Felhmann, 2010 \\
\hline & Hungary & \begin{tabular}{|l|} 
Starčevo-Criş- \\
Körös \\
\end{tabular} & c. $6200-5300$ & Ecsegfalva 23B & Metapodial & Ruminant & Choyke, 2007 \\
\hline & Serbia & $\begin{array}{l}\text { Starčevo-Criş- } \\
\text { Körös }\end{array}$ & c. $6200-5300$ & Starčevo-Grad & Metapodial & Ruminant & Vitezović, 2013a \\
\hline & Macedonia & \begin{tabular}{|l|}
$\begin{array}{l}\text { Anzabegovo-Vrš- } \\
\text { nik II-IV }\end{array}$ \\
\end{tabular} & c. $5800-5200$ & Madzhari & Metapodial & Ruminant & Sidéra, 2012 \\
\hline & \multirow[t]{2}{*}{ Grecia } & Early Neolithic & c. $6500-5800$ & Giannitsa & Metapodial & Ruminant & Sidéra, 2012 \\
\hline & & Proto-Sesklo & c. $6500-6000$ & Nea Nikomedeia & Metapodial & Ruminant & \begin{tabular}{|l|} 
Stratouli, 1999; \\
Sidéra, 2012 \\
\end{tabular} \\
\hline & \begin{tabular}{|l|} 
Bulgaria \\
\end{tabular} & \begin{tabular}{|l|} 
Early Neolithic \\
\end{tabular} & c. $6100-5800$ & Kovačevo & Metapodial & Ruminant & Sidéra, 2012 \\
\hline & \multirow[t]{2}{*}{ Romania } & \multirow{2}{*}{$\begin{array}{l}\text { Starčevo-Criş- } \\
\text { Körös }\end{array}$} & \multirow[t]{2}{*}{ c. $6200-5300$} & Negrilești & Metapodial & Ruminant & Beldiman et al., 2012 \\
\hline & & & & \begin{tabular}{|l|}
$\begin{array}{l}\text { Şeuşa - "La cărarea } \\
\text { morii"" }\end{array}$ \\
\end{tabular} & Metapodial & Ruminant & $\begin{array}{l}\text { Beldiman and Sztancs, } \\
2013 \\
\end{array}$ \\
\hline \multirow{13}{*}{$\begin{array}{l}\text { Segmentation } \\
\text { with abrasive } \\
\text { fibres }\end{array}$} & \multirow[t]{3}{*}{ Spain } & \multirow[t]{3}{*}{ Neolithic I } & \multirow[t]{3}{*}{ c. $5600-4500$} & Cova de la Sarsa & \multirow{3}{*}{$\begin{array}{l}\text { Femur; } \\
\text { Diaphysis }\end{array}$} & \multirow{3}{*}{$\begin{array}{l}\text { Ruminant and } \\
\text { Indeterminate }\end{array}$} & Llobregat et al., 1981; \\
\hline & & & & Cova de la Cendres & & & $\begin{array}{l}\text { Sénépart, 1984; } \\
\text { Pascual Benito, } 1996\end{array}$ \\
\hline & & & & Fosca & & & \\
\hline & France & Rubané & c. $5500-4700$ & Cuiry-lès-Chaudardes & Diaphysis & Indeterminate & Sidéra, 2005, 2012 \\
\hline & & & & Berry-au-Bac & Diaphysis & Indeterminate & Sidéra, 1995 \\
\hline & & & & Ensisheim & Diaphysis & Indeterminate & Sidéra, 2000b \\
\hline & & Chasséen & c. $4200-3500$ & Wettolsheim & Diaphysis & & Sidéra, 2000b \\
\hline & Hungary & \begin{tabular}{|l} 
Starčevo-Körös- \\
Criș \\
\end{tabular} & c. $6200-5300$ & Ecsegfalva 23B & Diaphysis & Indeterminate & Choyke, 2007 \\
\hline & Serbia & $\begin{array}{l}\begin{array}{l}\text { Starčevo-Körös- } \\
\text { Criș }\end{array} \\
\end{array}$ & c. $6200-5300$ & Starčevo-Grad & Diaphysis & Indeterminate & Vitezović 2013a \\
\hline & Bulgaria & \begin{tabular}{|l} 
Early Neolithic \\
\end{tabular} & c. $6100-5800$ & Kovačevo & Diaphysis & Indeterminate & Sidéra, 2005, 2012 \\
\hline & Romania & Boian & c. $5000-4500$ & Radovanu & Tibia & Ovis/Capra & Mărgărit et al., 2014b \\
\hline & & & & Issacea & \begin{tabular}{|l|} 
Diaphysis \\
\end{tabular} & Indeterminate & Micu, 2004 \\
\hline & & Hamangia & c. $5200-4500$ & Cheia & \begin{tabular}{|l|} 
Femur; \\
Diaphysis \\
\end{tabular} & $\begin{array}{l}\text { Ovis/Capral } \\
\text { Capreolus } \\
\end{array}$ & Voinea et al., 2014 \\
\hline $\begin{array}{l}\text { Perforation by } \\
\text { wear technique }\end{array}$ & Hungary & \begin{tabular}{|l|}
$\begin{array}{l}\text { Starčevo-Körös- } \\
\text { Criș }\end{array}$ \\
\end{tabular} & c. $6200-5300$ & Ecsegfalva 23B & Diaphysis & & Choyke, 2007 \\
\hline & Bulgaria & Early Neolithic & c. $6100-5800$ & Kovačevo & \begin{tabular}{|l|} 
Diaphysis \\
\end{tabular} & Indeterminate & Sidéra, 2012 \\
\hline & Serbia & Starčevo-Körös- & c. $6200-5300$ & Čoka-Kremenjak & Diaphysis & Indeterminate & Vitezović, 2013a, \\
\hline & & Criş & & Starčevo-Grad & & & $2013 b$ \\
\hline & & & & Vizić-Golokut & & & \\
\hline & & & & Grivac & & & \\
\hline
\end{tabular}

TABLE 1

Examples of the use of wear techniques in the European Neolithic. 
Sheep (Ovis aries), goat (Capra hircus) or roe deer (Capreolus capreolus) metapodials are the raw materials that are always used. The cortical bone is divided with the purpose of obtaining of two standardized blanks with an artificial shape and rectangular section. Thus, the blanks have four sides. The surface of two of them is completely flat, entirely covered with parallel abrasion marks lying obliquely along the long axis of the piece. The abrasion marks are coarse, showing that a strongly abrasive stone was used to wear down the cortical layer and accelerate the division of the bone. The other two sides reveal the bone's natural structure including the medullary cavity and the diaphysis wall. Such grinding of the articular ends also produces a decorative shape at the same time. The method is associated with pointed tools and decorative pins.

The second type of the 'manufacture-by-wear' technique involved the production of regular, drilled perforations with circular morphologies and cylindrical sections. With this type of perforation, a preform preserves a perforation with completely smooth walls and with continuous fine drilling striations along the perforation wall. Small fragments of bone associated with this technique have been found. They have all the same wall characteristics and a cylindrical morphology. The presence of these small waste pieces demonstrate that the instrument used to make the perforation was hollow with a cylindrical morphology itself.

Segmentation with abrasive fibre was used in two transformative technological schemes. In the first scheme it was applied on long bones belonging to large and medium size species such as cattle (Bos taurus), aurochs (Bos primigenius), red deer (Cervus elaphus) and wild boar (Sus scrofa). The objective was to remove the epiphysis by using this procedure which produced a groove with polished concave walls and long, fine striations developing transversally to the long axis of the blank. Moreover, the procedure has been identified on debitage waste, but not on diaphyses, due to their thorough transformation in the shaping stage. In the second scheme, this technique was used to make rings. Here, the technique was used on diaphysis from medium sized ruminants (Ovis aries/Capra hircus/ Capreolus capreolus). To visualize the width of the intended blanks, a delineation procedure was applied by sawing with a lithic tool. In this way, a groove was drawn around the entire circumference of the bone. The process continued with seg- mentation by sawing with a fibre. The groove was also used to stop the thread from sliding until the groove was sufficiently deep to hold it in place. The technique produced a series of blanks, close to being finished, with diameters predefined by the size of the long bone diaphysis.

\section{Methodology of analysis}

To gather information about these techniques we integrated three types of data: 1) direct analysis of the archaeological material, 2) published technological records from other archaeological assemblages (Table 1) and 3) our own experimental approach. For the purposes of this research, we identified diagnostic pieces such as preforms, blanks and manufacturing waste mostly from the faunal assemblage itself, rather than finished pieces. The artifacts were studied at a macroscopic level where the correct characterization of technological marks is particularly important. Based on this, the succession of manufacturing gestures was reconstructed to visualize the transformation from block of unworked raw material to finished object. In addition, the archaeological and experimental marks were analyzed with an Olympus stereo-microscope (magnification up to 90X), and a Keyence VHX-600 digital optic microscope using lenses of variable strength between $30 \mathrm{X}$ and $100 \mathrm{X}$.

Bone replicas were produced based on the identified data on actual archaeological pieces. These replicas provided an overview of the variable techniques used in processing osseous materials. A descriptive chart including all the stages of the operational scheme was used providing detail on raw material type, the time necessary for each type of operation, the tools we have worked with, and the results obtained for each operation (macro-marks). However, we have an obligation to specify that the necessary time commitment is always relative because none of the participants can claim the knowhow of people who have been doing these crafts since childhood. The time it takes for us to progress through these actions is likely to be radically different than the time taken by an adult in any of these Neolithic societies. Consequently, it takes as many experiments as possible to gain experience and improve our workload. Also, we did not always have access to identical bones types as those used by the Neolithic communities. All these de- 
tails highlight that the results of any experimental approach should be accepted with caution.

The purpose for the seriation of these charts is to create a referential database which, by constantly gathering information, related to all the variables involved in the implementation of the three 'manufacture-by-wear' techniques. Unfortunately, the experiment gives us a truncated picture of the prehistoric community technology: it can show us what was done but not why it was done. There are many ways to solve most technical requirements and we can imagine that the prehistoric craftsmen tried all these technological innovations and most of them failed and were abandoned. It is impossible for us to reconstitute all the ways that finally led to the adoption of these three technological solutions.

\section{Archaeological assemblage}

The settlement of Măgura-Buduiasca (Figure 1) is located in southern Romania, on a lower terrace of Teleorman river, within the south-east part of Măgura village. It was discovered in 2001 and archeologically researched during 2001-2008. The dimensions are approx. $850 \times 350 \mathrm{~m}$ on the eastwest and north-south axes, with a surface of almost 30 ha. Throughout the researched surface of the site, which sums to $400 \mathrm{~m}^{2}$, the archeological levels do not present the same consistency. The stratigraphic analysis of the relevant profiles from the archeological sections and samplings revealed elements that enable temporal relations between the different Neolithic levels to be specified. From the perspective of absolute chronology, a series of $32{ }^{14} \mathrm{C}$ data outlines the evolution of this settlement: Starčevo-Criș I - c. 6000-5900 cal BC, Starčevo-Criș III - c. 5800-5700 cal BC, Dudești - c. 5500-5300 cal. BC and Vădastra - c. 5200-5000 cal BC. (Table 2). During the archeological excavations assemblages that belong to the entire sequence of the Neolithic were examined. After analyzing their structure, the type of inventory and the manner in which the different categories of materials were associated, they were interpreted as different constructions, including dwellings, pits and waste areas, and deposits with ritual character. The inventory of the assemblages generally consists of ceramic fragments,

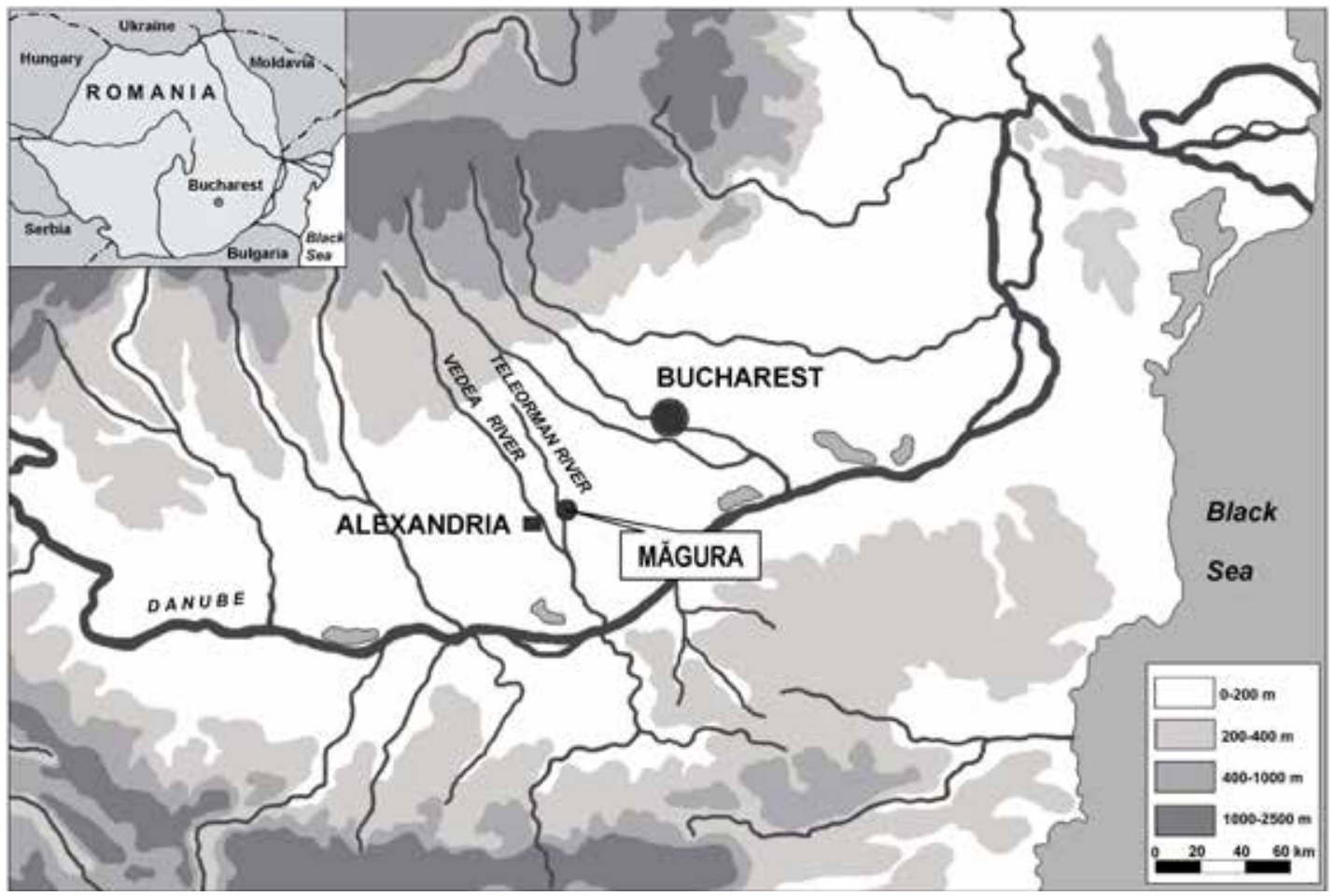

FIGURE 1

Location of the Măgura-Buduiasca settlement. Adapted after Balasse et al. (2013; fig. 1). 


\begin{tabular}{|c|c|c|c|c|c|c|}
\hline Lab. No. & Date BP & \pm & Cal BC $1 \sigma$ & Sample material & Level & References \\
\hline Poz-52552 & 7110 & 40 & $6030-5920$ & Animal bone & Starčevo-Criş I & \multirow{27}{*}{$\begin{array}{l}\text { Mirea, 2005, 2011; } \\
\text { Walker \& Bogaard, 2011; } \\
\text { Thissen, 2012, 2013; } \\
\text { Balasse } \text { et al., 2013; } \\
\text { Bălăşescu, 2014; } \\
\text { Evin } \text { et al., 2015 }\end{array}$} \\
\hline Poz-52554 & 7100 & 50 & $6030-5910$ & Animal bone & Starčevo-Criş I & \\
\hline UBA-9630 & 7107 & 29 & $6020-5930$ & Animal bone & Starčevo-Criş I & \\
\hline Poz-52553 & 7060 & 40 & $6000-5900$ & Animal bone & Starčevo-Criş I & \\
\hline UBA-9629 & 7031 & 31 & $5990-5890$ & Animal bone & Starčevo-Criş I & \\
\hline UBA-18097 & 6970 & 27 & $5900-5800$ & Animal bone & Starčevo-Criş I & \\
\hline UBA-18098 & 6959 & 28 & $5890-5790$ & Animal bone & Starčevo-Criş I & \\
\hline Wk-14436 & 6896 & 61 & $5850-5720$ & Animal bone & Starčevo-Criş III & \\
\hline OxA-21405 & 6868 & 38 & $5800-5710$ & Barley grain & Starčevo-Criş III & \\
\hline Wk-14437 & 6833 & 53 & $5760-5660$ & Animal bone & Starčevo-Criş III & \\
\hline OxA-21406 & 6831 & 37 & $5740-5670$ & Barley grain & Starčevo-Criş III & \\
\hline Wk-14435 & 6784 & 56 & $5720-5640$ & Animal bone & Starčevo-Criş III & \\
\hline OxA-21407 & 6767 & 38 & $5710-5630$ & Wheat grain & Starčevo-Criş III & \\
\hline OxA-21403 & 6761 & 36 & $5710-5630$ & Barley grain & Starčevo-Criş III & \\
\hline OxA-21404 & 6278 & 37 & $5310-5220$ & Barley grain & Starčevo-Criş III * & \\
\hline OxA-16636 & 6543 & 37 & $5530-5470$ & Animal bone & Dudeşti & \\
\hline OxA-16633 & 6497 & 35 & $5510-5380$ & Animal bone & Dudeşti & \\
\hline OxA-16637 & 6484 & 37 & $5490-5380$ & Animal bone & Dudeşti & \\
\hline OxA-16630 & 6463 & 40 & $5480-5370$ & Animal bone & Dudeşti & \\
\hline OxA-16634 & 6454 & 39 & $5480-5370$ & Animal bone & Dudeşti & \\
\hline OxA-16641 & 6415 & 45 & $5470-5360$ & Animal bone & Dudeşti & \\
\hline OxA-16969 & 6371 & 37 & $5470-5310$ & Animal bone & Dudeşti & \\
\hline OxA-16635 & 6354 & 37 & $5380-5300$ & Animal bone & Dudeşti & \\
\hline OxA-28791 & 6238 & 34 & $5310-5080$ & Animal bone & Vădastra & \\
\hline OxA-16632 & 6260 & 35 & $5300-5210$ & Animal bone & Vădastra & \\
\hline OxA-24693 & 6260 & 34 & $5300-5210$ & Animal bone & Vădastra & \\
\hline OxA-16631 & 6130 & 40 & $5210-4990$ & Animal bone & Vădastra & \\
\hline
\end{tabular}

TABLE 2

Radiocarbon dates for the cultural levels of Măgura-Buduiasca settlement. * This date corresponds to the Vădastra level.

animal bones, shells valves, stones, bone and flint tools, anthropomorphic and zoomorphic figurines, and adornments.

The bipartion by abrasion technique appears in the oldest Starčevo-Criș level, but had disappeared at the Dudești level and does not reappear in subsequent levels (Table 3). This procedure seems to be replaced by pointed tools produced on ribs, obtained by longitudinal bipartition using diffuse direct percussion or longitudinal scraping. One fragment of caprine distal epiphysis metacarpus bone is extremely interesting. It most likely represents waste from manufacturing (Figure 2a) (Mărgărit et $a l ., 2014 a)$. Only one epiphysis is preserved and a small part of the diaphysis wall. This piece eloquently illustrates how these points were shaped by bipartition. Both the dorsal and palmar faces of the diaphysis were heavily abraded (Figures 2b, d) producing a rectilinear appearance. This action continued until the two preforms were detached from each other. A block of this type, entirely preserved, is mentioned from the site of Starčevo-Grad - Serbia (Vitezović, 2013a; fig. 12). Returning to Măgura-Buduiasca, the bipartition was noticed on a few caprine metapodials (seven specimens) transformed into pointed tools (Figure 2c). The technique was observed on seven other pieces with different fragmentation degrees. The possibility cannot be excluded that these objects might actually have been finished pieces, more precisely pointed tools.

This technical procedure is present throughout the Early Neolithic in the Balkans (e.g., the settlements of Kovačevo - Bulgaria (Sidéra, 2012; fig. 25), Madzhari - Macedonia (Sidéra, 2012; fig. 25), Starčevo-Grad - Serbia (Vitezović, 2013a) or 


\begin{tabular}{|c|c|c|c|c|c|c|c|c|c|c|c|}
\hline \multirow[t]{2}{*}{ Period } & \multirow[t]{2}{*}{ Culture } & \multirow[t]{2}{*}{ Dating (BC) } & \multicolumn{3}{|c|}{ Bipartition by abrasion } & \multicolumn{3}{|c|}{ Perforation by wear technique } & \multicolumn{3}{|c|}{ Segmentation with abrasive fibre } \\
\hline & & & Species & Bone & \begin{tabular}{|c|}
$\begin{array}{c}\mathrm{N}^{\circ} \\
\text { pieces }\end{array}$ \\
\end{tabular} & Species & Bone & \begin{tabular}{|c|}
$\mathrm{N}^{\circ}$ \\
pieces
\end{tabular} & Species & Bone & $\begin{array}{c}\mathrm{N}^{\circ} \\
\text { pieces }\end{array}$ \\
\hline \multirow{8}{*}{$\begin{array}{l}\text { Early } \\
\text { Neolithic }\end{array}$} & \multirow{8}{*}{\begin{tabular}{|l|} 
Starčevo \\
-Criş
\end{tabular}} & \multirow[t]{8}{*}{ c. $6200-5300$} & \multirow{8}{*}{\begin{tabular}{|l|} 
Ovis/Capral \\
Capreolus
\end{tabular}} & \multirow[t]{8}{*}{ Metapodial } & \multirow[t]{8}{*}{15} & \multirow[t]{8}{*}{ Indeterminate } & \multirow[t]{8}{*}{ Diaphysis } & \multirow[t]{8}{*}{5} & \multirow[t]{5}{*}{ Bos taurus } & Metatarsus & 3 \\
\hline & & & & & & & & & & Metacarpus & 3 \\
\hline & & & & & & & & & & Femur & 1 \\
\hline & & & & & & & & & & Humerus & 1 \\
\hline & & & & & & & & & & Tibia & 1 \\
\hline & & & & & & & & & $\begin{array}{l}\text { Bos } \\
\text { primigenius }\end{array}$ & Metacarpus & 1 \\
\hline & & & & & & & & & $\begin{array}{l}\text { Cervus } \\
\text { elaphus }\end{array}$ & Tibia & 1 \\
\hline & & & & & & & & & Indeterminate & Diaphysis & 12 \\
\hline \multirow{11}{*}{$\begin{array}{l}\text { Middle } \\
\text { Neolithic }\end{array}$} & \multirow{11}{*}{ Dudeşti } & \multirow{11}{*}{ c.5500-5000 } & \multirow[t]{11}{*}{-} & \multirow[t]{11}{*}{-} & \multirow[t]{11}{*}{-} & \multirow[t]{11}{*}{ Indeterminate } & \multirow[t]{11}{*}{ Diaphysis } & \multirow[t]{11}{*}{12} & \multirow[t]{5}{*}{ Bos taurus } & Femur & 7 \\
\hline & & & & & & & & & & Metatarsus & 4 \\
\hline & & & & & & & & & & Metacarpus & 1 \\
\hline & & & & & & & & & & Tibia & 1 \\
\hline & & & & & & & & & & Radius & 1 \\
\hline & & & & & & & & & \multirow[t]{2}{*}{ Ovis/Capra } & Femur & 5 \\
\hline & & & & & & & & & & Humerus & 2 \\
\hline & & & & & & & & & \multirow[t]{2}{*}{ Sus sp. } & Femur & 3 \\
\hline & & & & & & & & & & Tibia & 1 \\
\hline & & & & & & & & & \multirow[t]{2}{*}{ Indeterminate } & Diaphysis & 28 \\
\hline & & & & & & & & & & Femur & 1 \\
\hline \multirow{2}{*}{$\begin{array}{l}\text { Early } \\
\text { Chalcoli- } \\
\text { thic }\end{array}$} & \multirow[t]{2}{*}{ Vădastra } & \multirow[t]{2}{*}{ c. $5000-4800$} & - & - & - & Indeterminate & Diaphysis & 2 & Indeterminate & Diaphysis & 4 \\
\hline & & & & & & & & & $\begin{array}{l}\text { Cervus } \\
\text { elaphus }\end{array}$ & Tibia & 1 \\
\hline
\end{tabular}

TABLE 3

Descriptive table of the analyzed pieces from the Măgura-Buduiasca settlement worked osseous assemblage.

Ecsegfalva 23B - Hungary (Choyke, 2007)). It is attested north of the Danube, in Romania, by example at Negrilești (Beldiman et al., 2012) and Şeuşa (Beldiman \& Sztancs, 2013).

As with the previous technique, the perforation by wear appears in this region in the Early Neolithic. Unfortunately, archaeologists often treat the perforated bone pieces only in a general sense without detailing how the perforations were produced. Moreover, the debris generated by perforation activity (round debris with a medium diameter from 6 to $9 \mathrm{~mm}$ ) (Figures 3a-h), the key for deciphering this technique, were not recovered during the excavations due to their small dimensions. The small objects tend to be lost where no sieving or flotation sampling is used during the excavation, methods not very often applied especially in the older archaeological excavations. Moreover, archaeologists did not always recognize the special potential of these pieces (even if they recovered them), for identifying the technical choices of the studied prehistoric communities. Belt elements (Figures 3i, j) or rings (Figures $3 \mathrm{k}, 1$ ) could be manufactured from these preforms. Certainly, such examples should be far more numerous but, for the moment, without better excavation and reporting techniques, in the Romanian Neolithic this perforation type is only attested at Măgura-Buduiasca. Two perforated pieces come from the Starčevo-Criș level alongside another three perforation remains. In the Dudești level, there are nine pieces where the marks of this type of perforation technique are preserved, as well as three pieces of waste from perforation work. Finally, two items from the Vădastra level also preserve this type of perforation (Table 3). In the wider area of Starčevo-Körös-Cris culture, this perforation procedure was identified at Čoka-Kremenjak, Starčevo-Grad, Vizić-Golokut and, probably, Grivac (Vitezović, 2013a, 2013b; fig. 11), while Choyke (2007) identified it at Ecsegfalva 23B.

The appearance of segmentation with an abrasive fibre is connected, again, with the StarčevoKörös-Criș culture (Sidéra, 2012; fig. 19) and is mentioned at Starčevo-Grad (Vitezović, 2013a), Kovačevo (Sidéra, 2012) and Ecsegfalva 23B (Choyke, 2007). As we noted in the methodological section, the use of this segmentation technique at Măgura-Buduiasca is connected to two different 

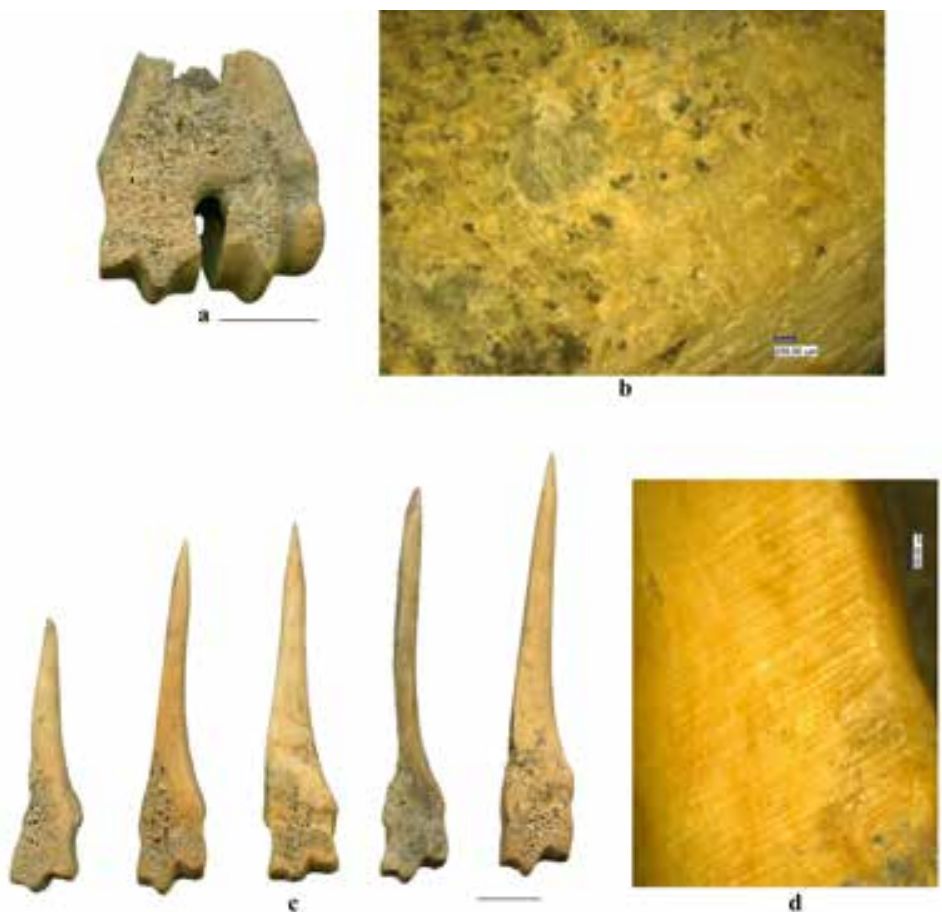

FIGURE 2

Archaeological evidence for the bipartition by abrasion technique: debitage waste (a); details of the abraded surface (b), (d); finished items (c). (Măgura-Buduiasca, Starčevo-Criș I level). (Photo by M. Mărgărit).

objectives: 1) dividing the diaphysis of large bones so that the cortex of the bone wall could be used subsequently for manufacturing (Figures $4 a-d$ ) and 2) for the production of a series of rings preserving the volume of the blank (Figures $4 \mathrm{e}-\mathrm{g}$ ). In the Starčevo-Cris level, the division of the diaphysis is attested by 20 specimens although rings were obtained in only three cases. For Dudești levels, the number of examples increases to 38 cases in which the epiphysis was eliminated and 16 rings were obtained (at different stages of manufacture - from marking out future rings, to creation of segmented blanks and, finally, finished pieces). For the final Vădastra level three rings and two segmented diaphysis were identified (Table 3).

\section{Experimental replica}

We must specify that all the bones in our experiments were processed either immediately after the slaughter of the animal or have been frozen until the time of processing (in order not to lose water from the tissue, which would make the bone more breakable). None of the bones were heat treated because there is big difference between cooked bone and green bone in the way it reacts to technological processing.

\section{Bipartition by abrasion}

For the experimental reconstruction of the operational chain, a single metapodial from a 12 month old goat (Capra hircus; Figure 5a) was used. Choosing this type of bone was not accidental, which is most often found in archaeological assemblages for the bipartition by abrasion technique (see Methodology section). Unfortunately, we could not acquire a bone from an adult specimen as were used in the Neolithic. Bones from younger specimens are easier/faster to process but the resulting blanks are less resistant. Again, we emphasize the limits of the archaeological experiment, especially for restoring the processing times for each technique. 


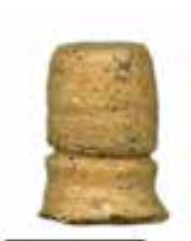

a

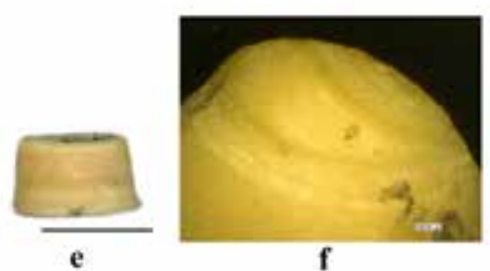

e

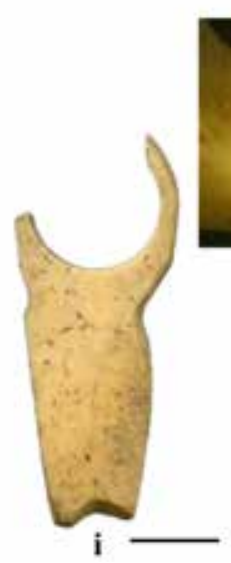

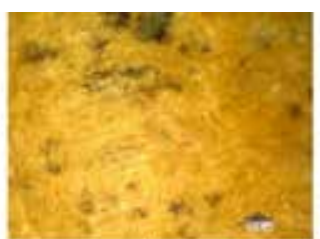

b

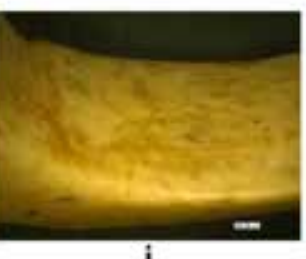

j

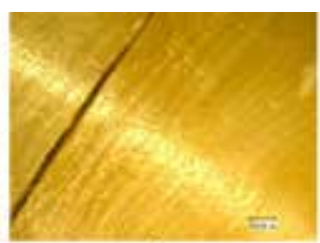

d

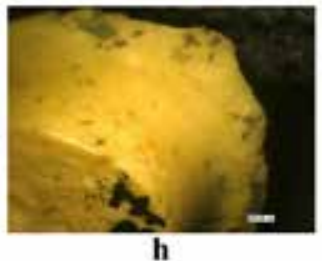

h

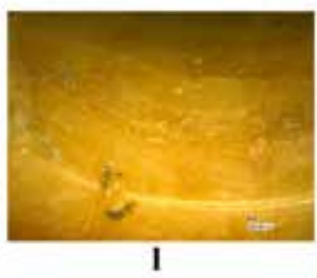

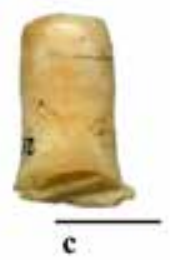
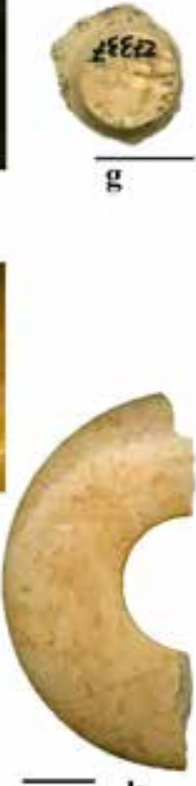

k

FIGURE 3

Archaeological evidence for the perforation-by-wear technique: perforation wastes (a), (c), (e), (g); details of the wear technique (b), (d); side-slips from the perforation pattern (f); macroscopic view of the perforation wall (h); belt element (i); details of the perforation (j), (l); ring (k). (Măgura-Buduiasca: (a), (c) - Starčevo-Criș I level; (e), (g), (i), (k) - Dudești level). (Photo by M. Mărgărit).

Using linear friction (Figure 5b), the method of bipartition by abrasion was applied by alternative abrasion of both dorsal and plantar surfaces until the medullary cavity was reached (Figure 5c-f). A very abrasive stone was used over which water was periodically poured. The procedure was lengthy and took $1 \mathrm{hr} 45$ minutes. It did not require constant physical effort but rather a controlled uniform movement. At the end of this transformation scheme, two regular blanks were obtained, both with a rectangular cross-section (Figure 5h) and two flat sides, close to the form of the future final object. The parallel abraded striations, generally lying obliquely to the long axis of the piece, entirely cover the processed surface. This manner of obtaining blanks requires greater time investment initially and less effort for the second part of the operation: the shaping. Thus, one of the halves was detached very easily with a direct percussive blow on the epiphysis. Then this half metapodial was rapidly transformed (4 minutes) into a point by abrasion at the active end, to provide convergence of the sides (Figure 5g).

\section{Perforation by wear technique}

The manner of how this technique was applied raised some procedural problems, the only certainty being the fact that the holes were produced by a non-lithic drill head that was hollow on the inside (thus creating special waste from perforation), perhaps with the addition of an abrasive material such as sand that created a strong macroscopic polish 


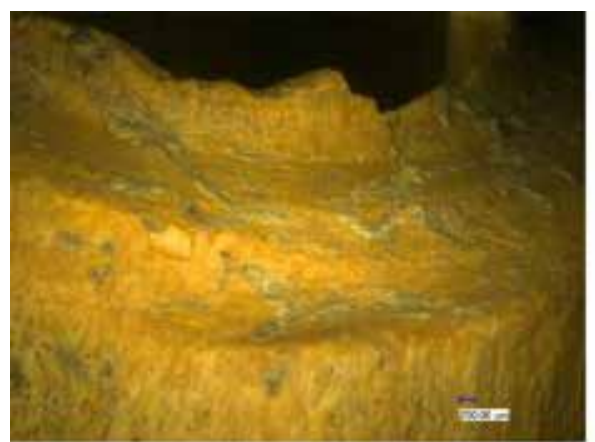

b

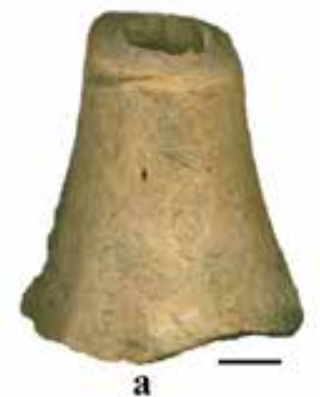

a

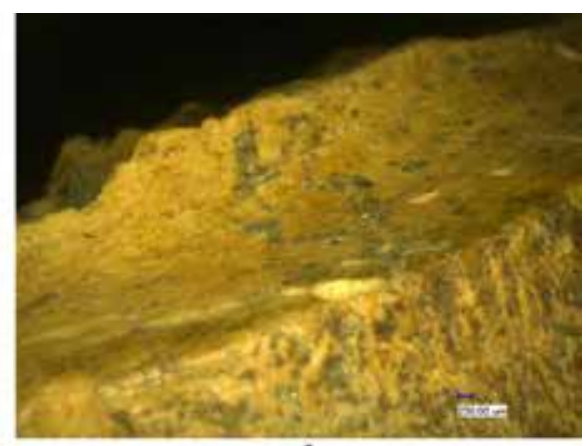

d
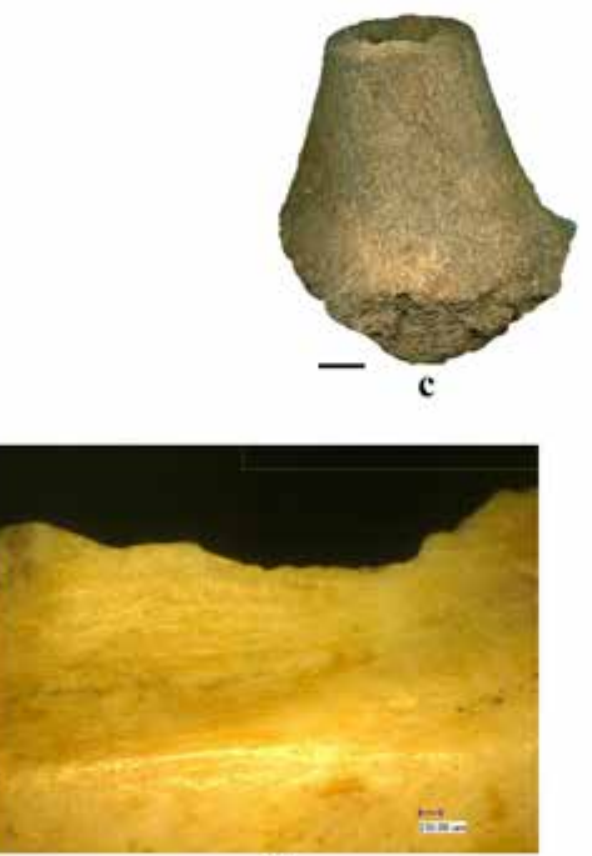

g

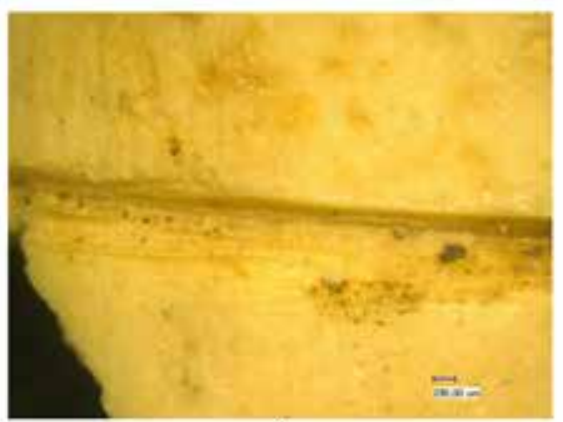

f

\section{FIGURE 4}

Archaeological evidence for the method of segmentation with abrasive fibre: epiphysis eliminated by segmentation (a - cattle metatarsus), (c - cattle femur); details of the segmentation groove (b), (d); blank and finished item illustrating the technique of segmentation for rings produced on blanks in volume (e); technique of delineation using a lithic tool (f); detail of the segmentation groove (g). (Măgura-Buduiasca, Dudești level). (Photo by M. Mărgărit). 


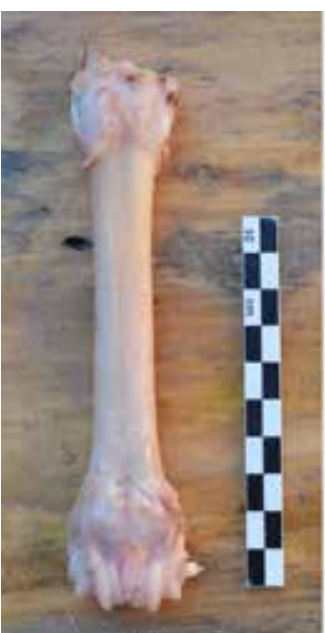

a

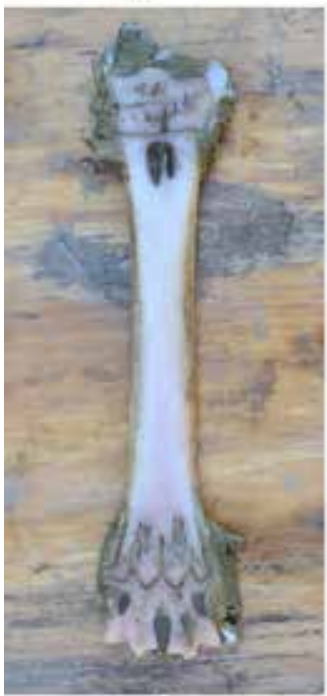

d

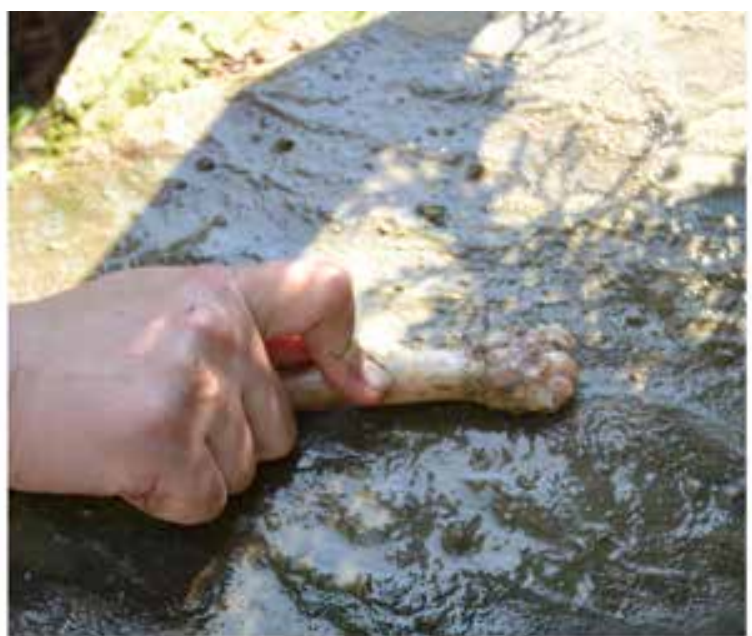

b

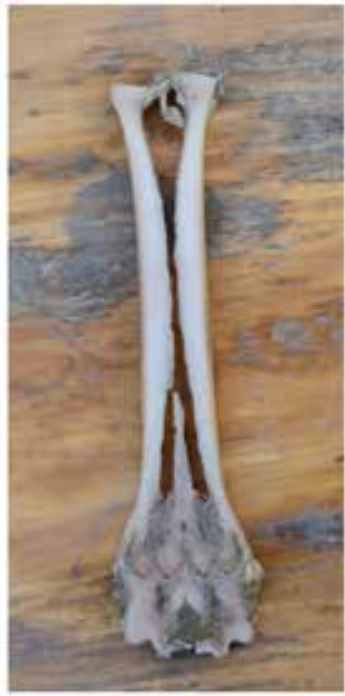

e

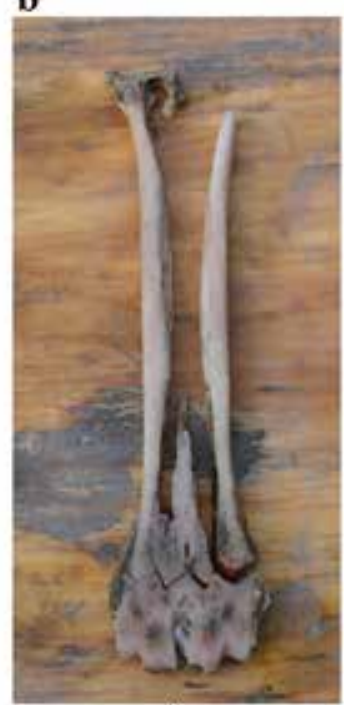

f

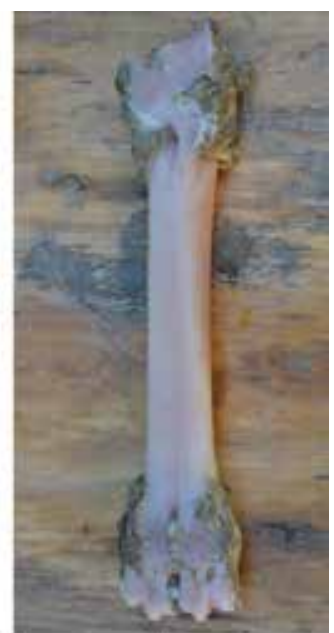

c
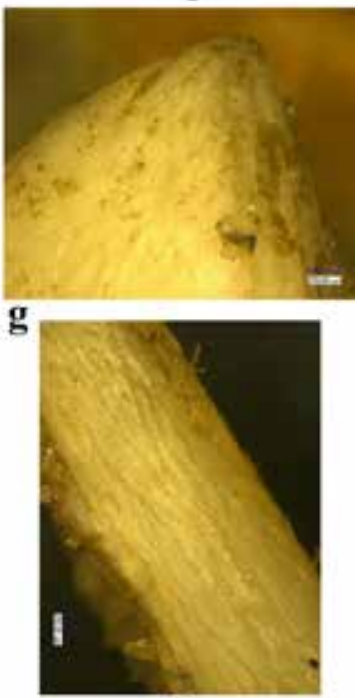

h

\section{FIGURE 5}

Experimentation of the bipartition method by abrasion: stages of the processing procedure (a)-(f); details of the abraded surface (g), (h). (Photo by M. Mărgărit).

visible under magnification. The material which seemed best adapted to this procedure was reed stems with the occasional addition of sand and water. During this work, the hand glides down to the bottom of the tubular reed, the length of the reed determining the amplitude of the movement (Figure 6a). In the first stage, this technique was used on a long goat bone that had been longitudinally fractured. It was clear why the perforation was produced on a flat blank: the rod would become blocked or slip in the medullary cavity so that the channel within which the perforation by wear tech- nique evolved cannot get started. Even under these conditions, it was very difficult to hold the stick steady within the form of the initial channel. Such side-slips are obvious on numerous pieces of perforation waste (Figure $7 \mathrm{f}$ ). The perforation work was finished in 50 minutes, and the result was a perfectly cylindrical perforation (Figures 6b-d) and a small piece of perforation waste (Figure 6e). This waste had to be detached as it comprised a small part still trapped in the material block because the rotation procedure could no longer be continued and appearing like a small accident. This mark 
may also be seen on archaeological objects. The striations and polish developed on the perforation walls, both on preforms (Figure 6f) and on the resulting debris, are similar to those identified on archaeological objects.

In the second stage, the technique was used on a cattle femur (Bos taurus) (Figure 7a). The bone was fractured using diffuse direct percussion and one of the resulting longitudinal splinters was

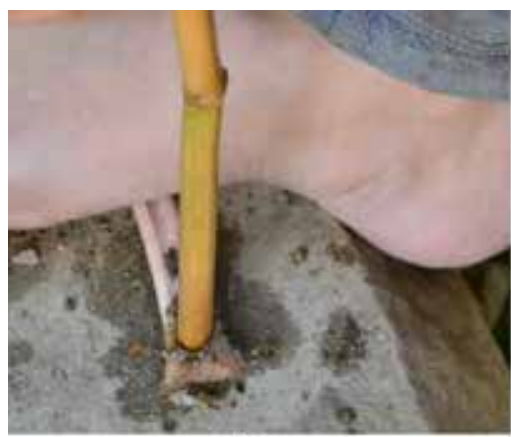

a

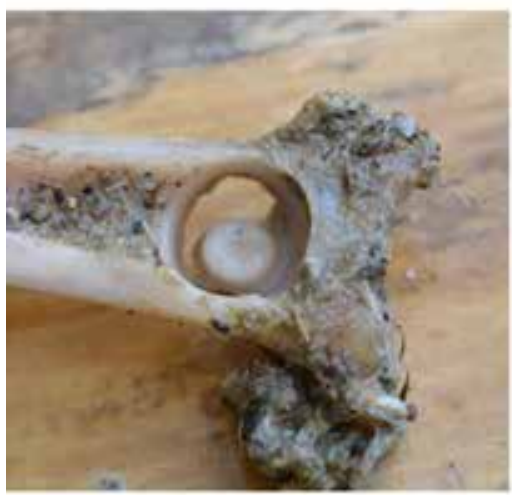

c

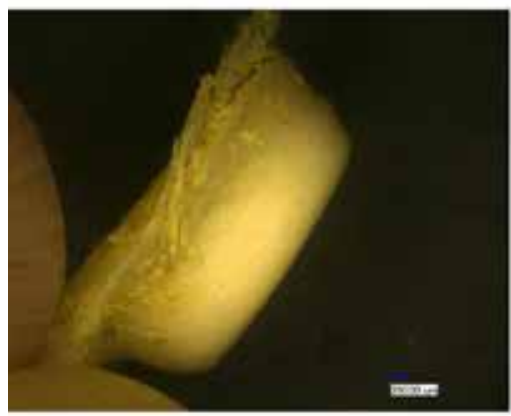

e selected from the diaphysis wall. A rod with an opening of $11 \mathrm{~mm}$ diameter could be used to create a perforation with a larger diameter $(9 \mathrm{~mm})$. The perforation work extended over a period of 2 hours and was extremely exhausting (well, for $21^{\text {st }}$ century soft urban dwellers anyway) (Figures $7 \mathrm{~b}-\mathrm{d})$. The results and observations are similar to those of the previous technical example (Figures $7 \mathrm{e}-\mathrm{g})$.

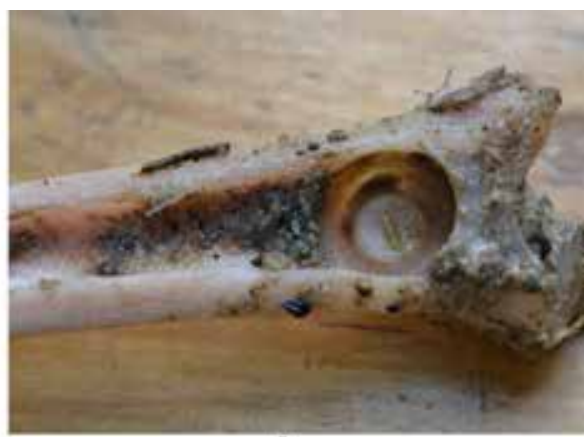

b

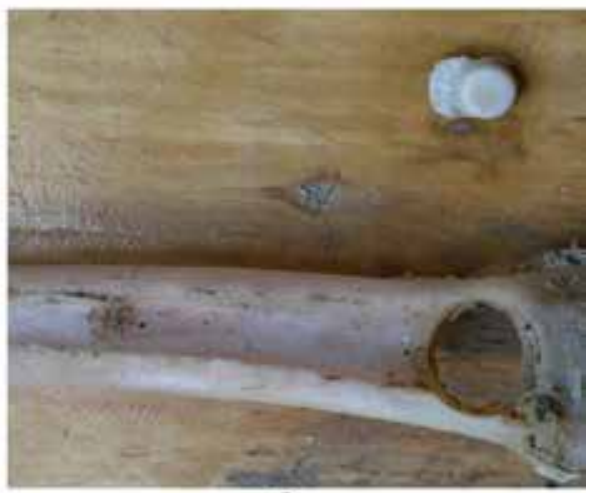

d

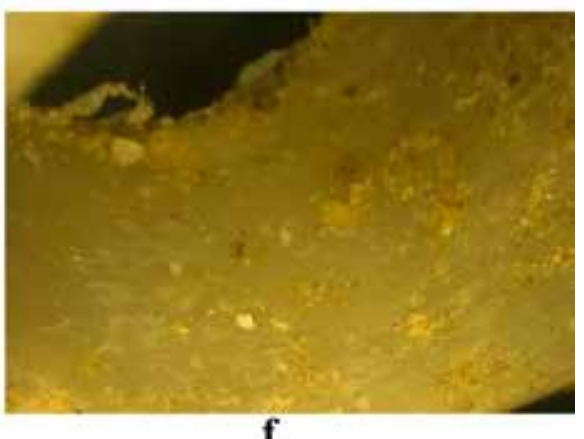

FIGURE 6

Experimentation on the perforation by wear technique on a metapodial goat: stages of the technological processing (a)-(d); perforation waste (e); detail of the perforation (f). (Photo by M. Mărgărit). 


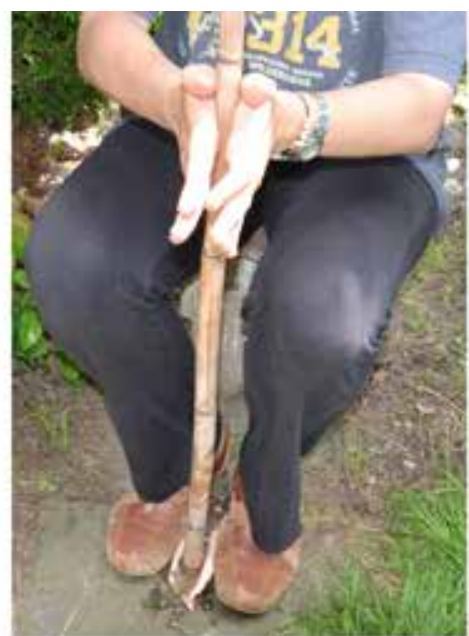

a

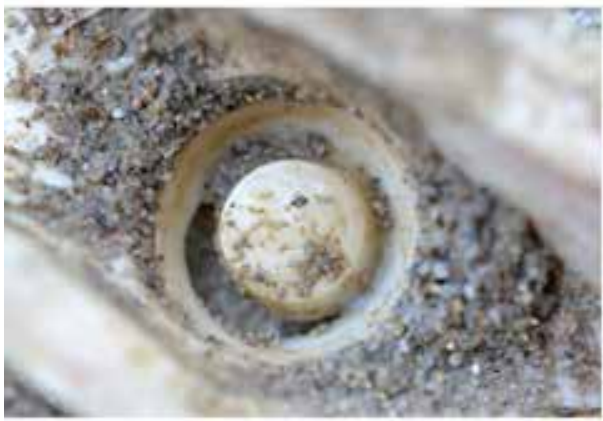

c

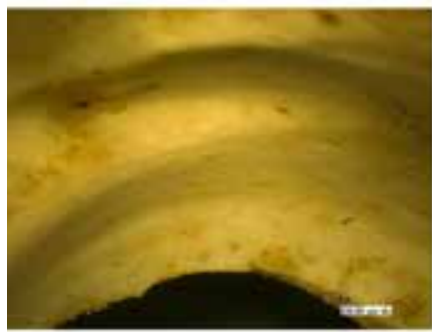

$\mathbf{e}$

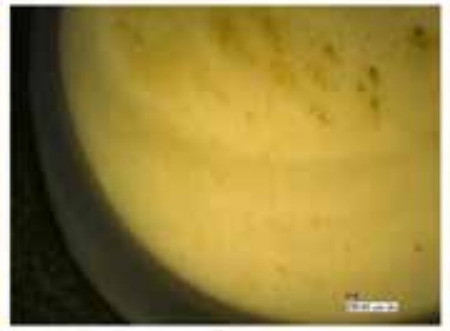

f

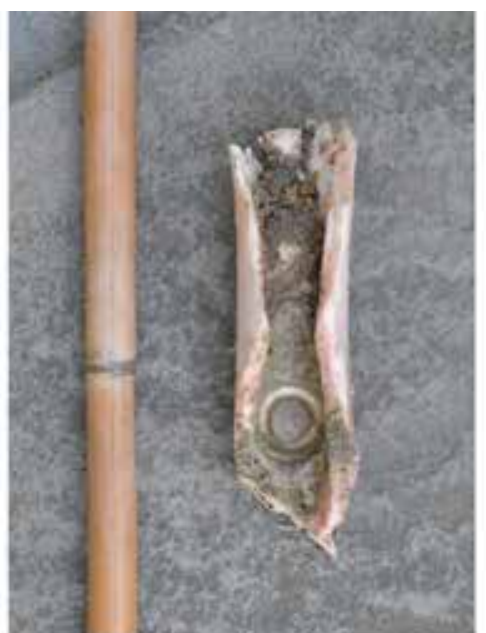

b

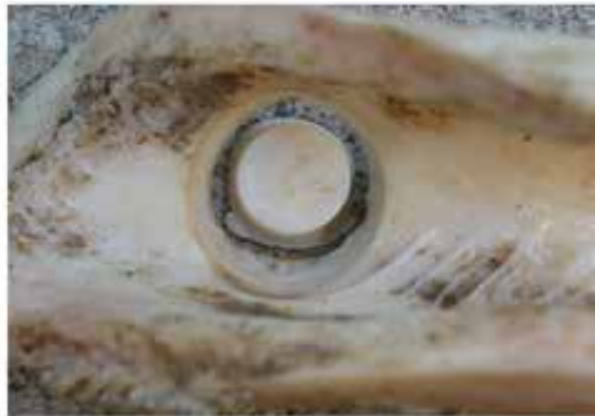

d

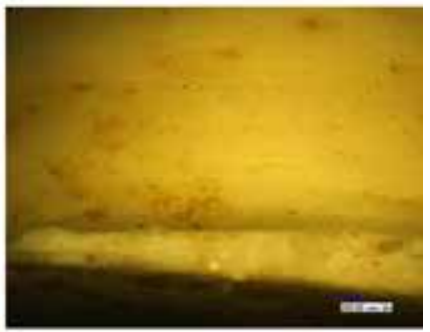

g

FIGURE 7

Experimentation on perforation by wear technique on a cattle femur: stages in the technological processing (a)-(d); detail of the perforation (e); side-slips from the perforation pattern (f); wall of the perforation waste (g). (Photo by M. Mărgărit).

\section{Segmentation with abrasive fibre}

The first segmentation procedure was used on a pig (Sus domesticus) femur (Figure 8a). The choice of this blank was constrained by availability, even though we are conscious of the fact that modern pig has less dense long bones (we again return to the limits of the experimental approach).
The purpose was the removal of epiphysis using sawing with an abrasive fibre, applied at both epiphyses. A thread made of vegetal fibre (hemp) was chosen which can be acquired already prepared. This type of material was chosen because it is very close to a plant fibre the Neolithic communities used and, in addition, is quite easy to obtain. Wet sand in combination with the string was em- 
ployed (Figure 8b). The time necessary to remove each epiphysis was about 20 minutes. The procedure is quite difficult during the first 5 minutes because the groove is not yet formed and the string slides and the trajectory must be straightened. Once the groove is sufficiently deep the method becomes very efficient. However, the segmentation cannot be finalized only by this procedure. At the end the bone must be detached by bending the epiphysis at the groove until it snaps off. The result appears as a snap flake that was also observed on the archaeological pieces. The bending cannot be applied prematurely, otherwise there is a possibility of an accidental crack appearing, creating an irregular fracture. The fibre of hemp broke many times and needed replacement. At the end, this work resulted in a blank and two pieces of debitage waste (Figure $8 \mathrm{c}$ ). Under a microscope (50x magnification) the

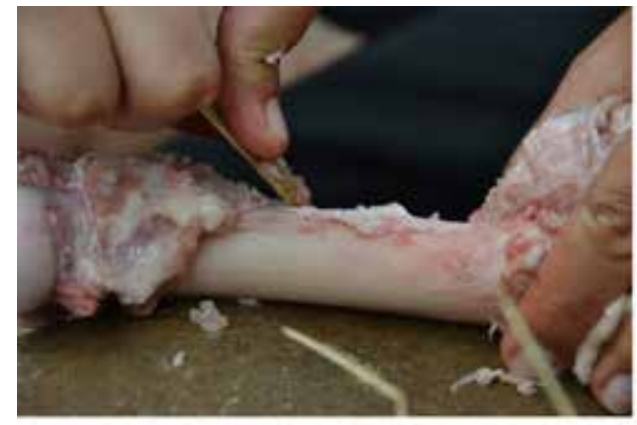

a

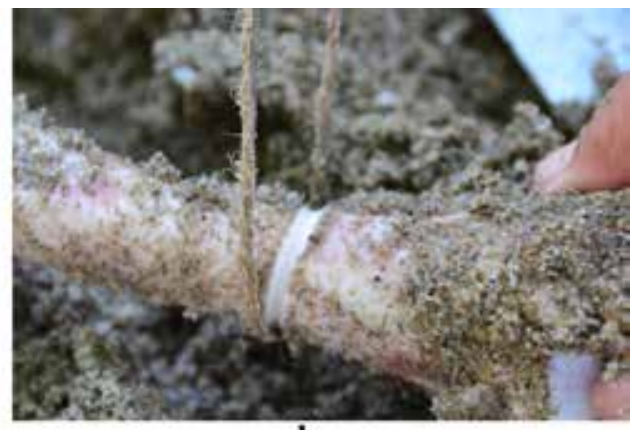

b

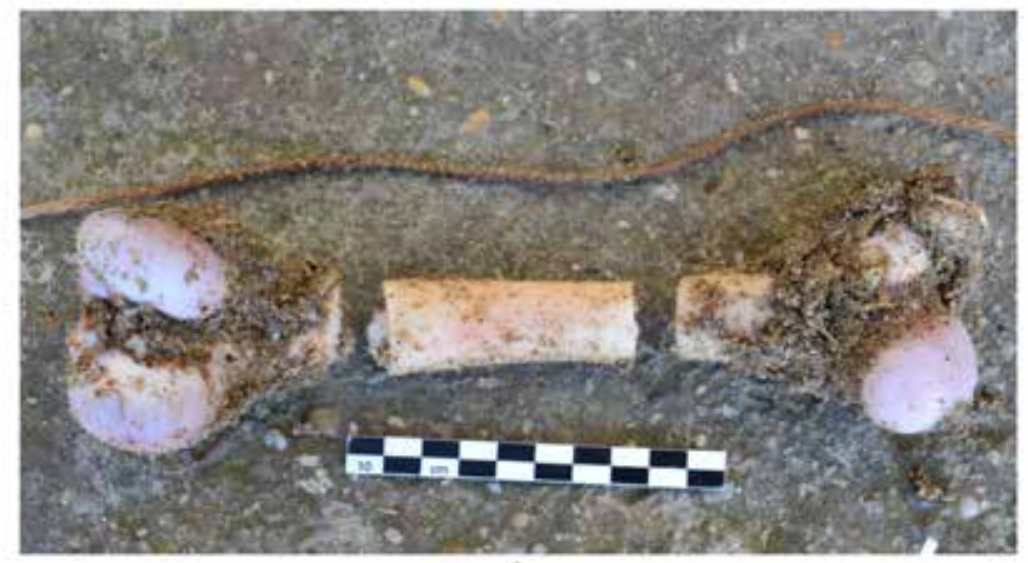

c

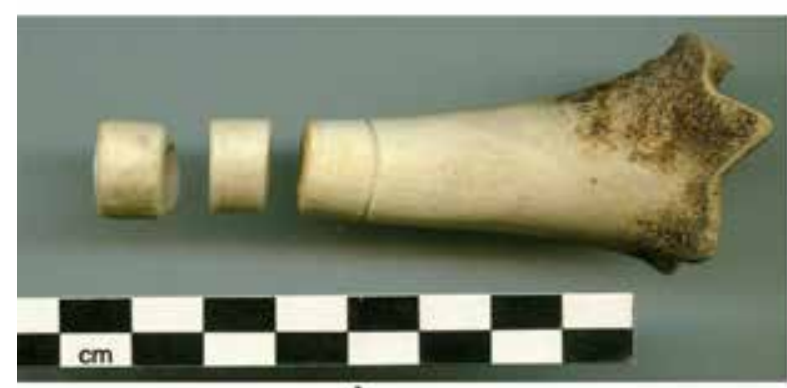

d

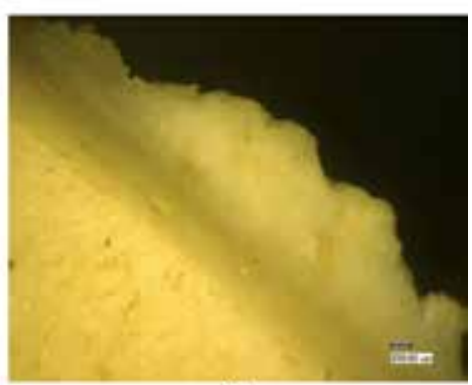

e

FIGURE 8

Experimentation on the segmentation procedure with plant fibre: stages in epiphysis elimination (a)-(c); processing rings by segmentation (d); detail of the segmentation groove (e). (Photo by M. Mărgărit). 
development of certain technological marks similar to those found on archaeological pieces can be seen: a polished wall with a slightly concave morphology and fine striations located transversally to the long axis of the piece (Figure 8e).

In a second stage of experimentation, the procedure for obtaining the rings (Figure 8d), following manufacturing stages identified on archaeological pieces was used: the delineation of the grooves with lithic tools with the final detachment of the epiphyses carried out by plant fibre string (the same type of hemp string). A sheep (Ovis aries) femur was used as the raw material. The procedure was quite quick and each one of the segmentations took approximately 7 minutes.

\section{RESULTS AND DISCUSSION}

Following the experiments and compared to the other techniques, it was very clear that a somewhat longer time is needed for the bipartition by abrasion of osseous blanks. However, among the examined assemblage, two other debitage methods by bipartition, producing the same results, were identified, the processing of two flat blanks which can be can further transformed into pointed tools. The alternative techniques where the debitage method was used are 1) the double grooving and 2) the indirect percussion. For this reason it was proposed that the technical scheme for these two procedures be reconstructed by experiment in order to permit a comparison with the previous experimental results. First, the bipartition by double grooving was reproduced. It required initiation of two grooves by unidirectional longitudinal movements using a burin type tool (Figure 9a). When the medullary cavity was reached the bony cortex was ready for bipartition. Bipartition of the two blanks was made using indirect percussion, this case requiring special attention to the force that hit the intermediary tool to avoid accidental cracks (Figure 9b). The result was two symmetrical blanks, obtained after approximately 40 minutes of work (Figure 9c). These blanks can be transformed into pointed tools quite rapidly by a combination of different techniques (scraping, abrasion, scraping + abrasion etc.). In the second case, bipartition by indirect percussion was reproduced, an action which produced usable blanks very quickly but which requires good control of the striking force otherwise the bone may be fragmented randomly (Figure 9d). There were a number of failures until the necessary strength to accomplish bipartition was determined, and two intact blanks were obtained. In the Early and Middle Neolithic assemblages of the studied region, all three methods coexist and no preference was noticed for any one.

The second technological procedure was the creation of a perforation through wear. It is slightly different from the previous technique. It is true that a perforation can also be created by bifacial rotation of a lithic tool. The operation takes approximately 30 minutes on the diaphysis of a bone of a large sized mammal (e.g. femur and metapodial of Bos taurus). However, this technique does not produce perforations uniform enough on both sides and with a regular diameter. In our opinion the disappearance of the procedure is connected with the disappearance of these decorative elements (belt elements and rings, Figure $3 \mathrm{i}, \mathrm{k}$ ) at the beginning of the Chalcolithic and by their replacement with other decorative elements which allow a faster technique for perforations.

For the third technique, epiphyses as debitage waste will be discussed. Using a hemp fibre string is a much faster procedure compared to segmentation by sawing using a lithic tool. Moreover, it does not require sustained physical effort, but rather constant bidirectional movement allowing the wear to develop. The procedure of epiphysis removal by sawing with a lithic tool has not been identified on bones from some large/medium sized mammals within the archaeological collections. The alternative procedure with similar results is direct percussion (Figure 9e). All that is needed is a massive lithic tool with a sharp edge and the application of a short, powerful strike. With only a couple of strikes a crack can be initiated allowing the epiphysis to be detached. The action can be continued with hits aimed around the entire circumference of the diaphysis or with detachment by bending where the risk still exists that the bone will break in an irregular manner, compromising the blank. The type of hammer appears to be very important because, in our own experiments, if a rounded hammer is used for diffuse percussion the result is the development of multiple longitudinal cracks creating fragments from which flat blanks are obtained (Figure 9f). In the case of rings, there is an obvious reason for using the segmentation procedure with abrasive fibre based string in preference to segmentation by percussion or even sawing with a lithic tool. Crafts- 


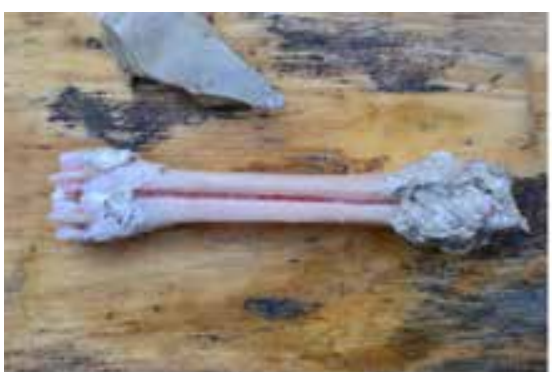

a

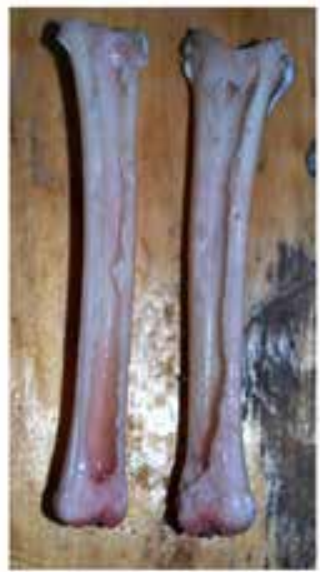

c

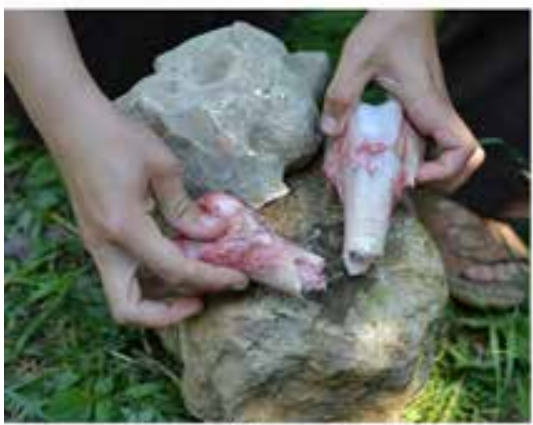

e

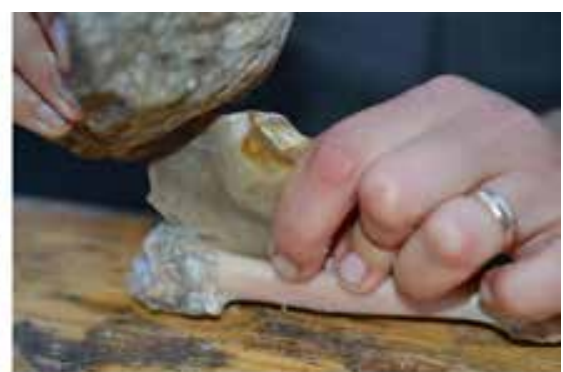

b

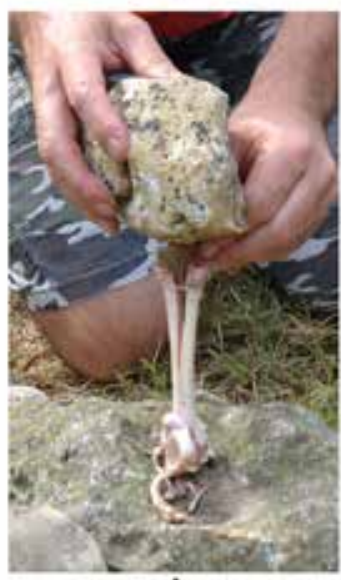

d

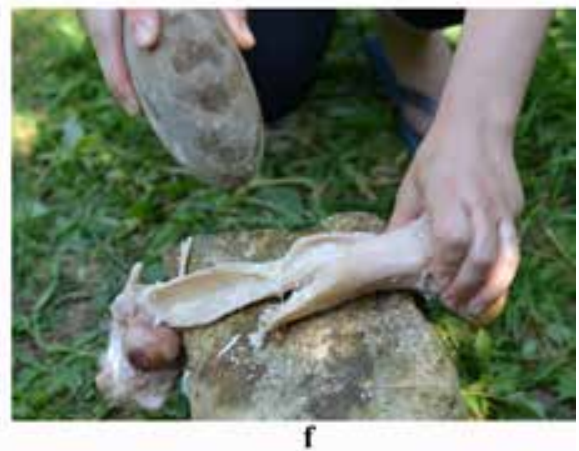

FIGURE 9

Experimentation on the bipartition and segmentation methods: stages of bipartition by double grooving (a)-(c); bipartition by indirect percussion (d); direct percussion (e); diffuse direct percussion (f). (Photo by M. Mărgărit).

people wanted to obtain regular blanks, a necessary condition for creating a desired aesthetic impact, with investment of minimum effort in the shaping stage. This is probably the reason why this procedure endured over the time. Thus, this manner of obtaining the rings is still present in the Early Chalcolithic assemblages of Radovanu (Boian Culture) (Mărgărit et al., 2014b), Isaccea (Boian Culture) (Micu, 2004; fig. 9) and Cheia (Hamangia Culture) (Voinea et.al., 2014).
At the technological level, the question asked at the beginning of the study was whether these procedures represented any kind of technological progress. In other words, was technological progress the reason why they were adopted or is a choice of technique more closely connected to local traditions of manufacture? Among the three main variants of longitudinal bipartition, the one using abrasion demands the greatest investment in time. At the end of the debitage operation two regu- 
lar blanks are obtained. Their form and dimensions may be pre-visualized, but these observations are also relevant for the procedure of double grooving. Using this technological alternative less than half the amount of time is needed compared to the first manufacturing technique. Although in the Balkans area this second manufacturing procedure is known and used from the beginning of the Neolithic until the end of the Chalcolithic, it never became dominant. The situation becomes even more intriguing regarding the method of bipartition using indirect percussion. At first sight, even if the investment in time is reduced, this debitage procedure appears to be imprecise with a high risk of accidental fractures. Thus, this technique does not allow the artisan to control the block of material. Nevertheless, in the studied Chalcolithic assemblages, where the procedure is, by far, the most intensively used, the amount of debitage waste with accidental cracks (unusable blanks) is low, showing the technological ability and know-how of the people. It seems that this last technique represented a technical development because the same types of blanks as with the previous procedures can be obtained with less technological effort and with a minimal use of time. The only difference that can be invoked is at an aesthetic level because the flattened diaphysis in section are sometimes more visually appealing than the unmodified partial epiphyses.

The same observations are applicable for the segmentation with abrasive fibre. For bones from large sized animals the procedure was strictly used to eliminate the epiphysis and only the diaphysis was used. Therefore, a major investment in time was needed to obtain debitage waste when, during the Chalcolithic, the epiphyses are eliminated by direct percussion in a couple of seconds. In this case, it should be concluded that the use of these technological procedures represented a cultural choice or at least was not limited to a technological one, a factor that also determined their abandonment or sporadic use during the Neolithic and Chalcolitic.

\section{CONCLUSION}

The processing of osseous materials is strongly conditioned by their anatomical form which is why a limited range of transformational variables was expected, with minimal variations during prehistoric times. However, numerous specialists invoke the cultural value conferred by the community as the preeminent element in the selection of raw material, rather than the limitations of the raw material form (see Introduction section). This makes the study of these three types of 'manufacture-by-wear' technique all the more interesting. These techniques are not found in all prehistoric periods in the region. Thus, north of the Danube, the segmentation technique with abrasive fibre is known in Mesolithic communities in the Iron Gates area (it is attested at the settlements of Ostrovul Banului, Alibeg and Ostrovul Corbului) (Beldiman, 2005; Mărgărit \& Boroneant, 2017; Mărgărit et al., 2017, in press) but it is used strictly for the processing of the Cervus elaphus antler. At the beginning of Neolithic the antler pieces almost disappear but the technique continues to be used and applied now to bone. The other two techniques are not present in Mesolithic assemblages and they appear suddenly at the beginning of the Neolithic. The technique of bipartition by abrasion had clearly disappeared at the end of the Early Neolithic. Segmentation made with plant fibres is well represented during the developed Neolithic and even in some Chalcolithic cultures (e.g. Boian and Hamangia), and entirely disappears in the Late Chalcolithic (e.g. Gumelnita Culture). It cannot be said that there was any kind of progress or improvement of efficiency in the ways in which osseous materials were processed, because the manufacturing techniques used in the Chalcolithic produced the same results but were apparently simpler with a reduced investment in time.

The study demonstrates that the variety of the transformation schemes for hard animal materials is greater than expected and that some methods were invented or, maybe, adopted from neighbouring areas (in the form of objects or ideas) and used only at certain periods of time and subsequently abandoned. Moreover, it becomes quite clear that it is strictly a matter of technical choice which procedures were associated with certain typological categories (rings on blank in volume - segmentation with string from plant fibres; belt elements and rings made on flat blanks - the perforation-by-wear technique). Given the technological data discussed above, the osseous material industry can also act as a cultural marker in addition to ceramic style as long as we can identify clearly the time these objects ceased to be manufactured using these techniques and the object type abandoned, perhaps 
with the influx of new people or ideas, changing socio-economic imperatives or even cultural breakdown.

Experimental reconstructions support these conclusions despite the limits of the archaeological experiment (which requires caution in interpreting the data). They aimed at better understanding the way in which technological traces evolve during processing, and, implicitly, the patterns observed on archaeological artefacts. It is necessary to continue these experimental activities to gain further experience and to reduce the time required in the processing of an artefact.

\section{ACKNOWLEDGMENTS}

We want to thank Dr. Alice Choye (Central European University, Budapest) who helped us in improving a first version of this paper. Also, many thanks are due to Dr. Steve Mills (Cardiff University) for reading this paper and for the English translation improvement.

This research was supported by two grants of the Romanian National Authority for Scientific Research, UEFISCDI: PN-III-P1-1.1-TE-2016-0182 (Monica Mărgărit) and PN-III-P4-ID-PCE-2016 -0676 (Adrian Bălășescu).

\section{REFERENCES}

B Allase, M.; BăLĂȘESCU, A.; JAnZEN, A.; Lughetto-MoNFrin, J.; Mirea, P. \& Andreescu, R. 2013: Early herding at Magura-Boldul lui Moș Ivănuş (early sixth millennium BC, Romania): environments and seasonality from stable isotope analysis. European Journal of Archaeology 16(2): 221-246.

BĂLĂŞESCU, A. 2014: Arheozoologia neo-eneoliticului de pe valea Teleormanului. Mega, Cluj Napoca.

Beldiman, C. 2005: Paleotechnology of antler working in the Mesolithic of the Iron Gates, Romania. In: Luik, H.; Choyke, A.M.; Batey, C.E. \& Lougas, L. (eds.): From Hooves to horns, from mollusc to mammoth. Manufacture and use of bone artifacts from Prehistoric Times to the Present. Proceedings of the $4^{\text {th }}$ Meeting of the (ICAZ) Worked Bone Research Group, Tallinn (Estonie), 26-31 août 2003: 33-46. Muinasaja Teadus 15 .
Beldiman, C. \& SzTancs, D.M. 2013: The osseous artefacts of the Starčevo-Criş culture in Romania. An overview. In: Comşa, A.; Bonsall, C. \& Nikolova, L. (eds.): Facets of the Past. The Challenge of the Balkan Neo-Eneolithic. Proceedings of the International Symposium Celebrating the $85^{\text {th }}$ Birth Anniversary of Eugen Comșa, 6-12 october 2008: 106-133. Academy Publishing House, București.

Beldiman, C.; Sztancs, D.M. \& Ilie, C. 2012: Artefacte din materii dure animale în colecția Muzeului de Istorie Galați. Eneolitic/Osseous Materials Artefacts in the Collection of History Museum Galați. Aeneolithic. Mega, Cluj Napoca.

Bosch Lloret, A.; Chincilla Sánchez, J.; Tarrus, I. \& Galter, J. 2000: El poblat lacustre neolitic de la Draga. Excavacions de 1990 a 1998. Centre d'arqueologia subaquatica de Catalunya (Monografies des Casc 2), Girona.

Bourdieu, P. 1977: Outline of a Theory of Practice. Cambridge University Press, Cambridge.

Choyke, A.M. 2005: Bronze Age Bone and Antler Working at the Jászdózsa-Kápolnahalom Tell. In: Luik, H.; Choyke, A.M.; Batey, C.E. \& Lõugas, L. (eds.): From hooves to horns, from mollusc to mammoth: 129-156. Muinasaja Teadus 15 .

- 2007: Objects for a lifetime - tools for a season: the bone tools from Ecsegfalva 23. In: Whittle, A. (ed.): The Early Neolithic on the Great Hungarian Plain. Investigations of the Körös culture site of Ecsegfalva 23, County Békés, vol II. Varia Archaeologica Hungarica, XXI: 641-666. Publicationes Instituti Archaeologici Academiae Scientiarum Hungaricae Budapestini, Budapesta.

- 2009: Grandmother's Awl: Individual and Collective Memory through Material Culture. In: Barbiera, I.; Choyke, A.M. \& Rasson, J. (eds.): Materializing Memory, Archaeological Material Culture and the Semantics of the Past: 21-40. B.A.R. (International Series) 1977. Oxford.

- 2013: Hidden Agendas: Ancient Raw Material Choice for Worked Osseous Objects in Central Europe and Beyond. In: Choyke, A. \& O'Connor, S. (eds.): From these Bare Bones: Raw Materials and the Study of Worked Osseous Materials: 1-13. Oxbow Books, Oxford.

- 2014: Continuity and discontinuity at Gyõr-SzabadrétDomb: bone tools from a Chalcolithic settlement in northwest Hungary/Continuitate și discontinuitate la Győr-Szabadrét-domb: unelte din os dintr-o așezare calcolitică din nord-vestul Ungariei. In: Mărgărit, M.; Le Dosseur, G. \& Averbouh, A. (eds.): An overview of the exploitation of hard animal materials during the Neolithic and Chalcolithic/O privire asupra exploatării 
materiilor dure animale de-a lungul neoliticului și calcoliticului: 295-315. Cetatea de Scaun, Târgoviște.

Choyke, A. \& Daroczi-Szabo, M. 2010: The Complete and Usable Tool: Some Life Histories of Prehistoric Bone Tools in Hungary. In: Legrand, A. \& Sidéra, I. (eds.): Ancient and Modern Bone Artefacts from America to Russia. Cultural, technological and functional signature: 235-248. B.A.R. (International Series) 2136. Oxford.

Choyke, A.m.; Vretemark, M. \& Sten, S. 2004: Levels of social identity expressed in the refuse and worked bone from the Middle Bronze Age Százhalombatta-Földvár, Vatya culture, Hungary. In: Jones, S.; Day, O.; van Neer, W. \& Ervynck, A. (eds.): Behavior Behind Bones. The Zooarchaeology of Ritual, Religion, Status and Identity: 177-189. Oxbow Books, Oxford.

CReswell, R. 1994: La nature cyclique des relations entre le technique et le social. Approche technologique de la chaîne opératoire. In: Latour, B. \& Lemonnier, P. (eds.): De la préhistoire aux missiles balistiques. L'intelligence sociale des techniques: 275-289. Editions La découverte, Paris.

Dobres, M.A. 2000: Technology and Social Agency: Outlining a Practice Framework for Archaeology. Blackwell Publishers, Oxford.

- 2010: Archaeologies of technology. Cambridge Journal of Economics 34: 103-114.

Evin, A.; Girdland Flink, L.; Bălășescu, A.; Popovici, D.; Andreescu, R.; Bailey, D.; Mirea, P.; Lazăr, C.; Boroneant, A.; Bonsall, C.; Strand Vidarsdottir, U.; Brehard, S.; Tresset, A.; Cucchi, T.; Larson, G. \& DoBNEY, K. 2015: Unravelling the complexity of domestication: a case study using morphometrics and ancient DNA analyses of archaeological pigs from Romania. Philosophical Transaction of the Royal Society B 370(1660): 1-7.

Fenlmann, D. 2010: Worked Bone, Tooth and Antler Objects from the Early Neolithic Site of Asparn/ZayaSchletz (Lower Austria). In: Legrand, A. \& Sidéra, I. (eds.): Ancient and Modern Bone Artefacts from America to Russia. Cultural, technological and functional signature: 31-40. B.A.R. (International Series) 2136. Oxford.

LemonNier, P. 1992: Elements for an anthropology of technology. Ann Arbor, Michigan.

Llobregat, E.; Martí Oliver, B.; Bernabeu, J.; Villaverde, V.; Gallart, M.D.; Pérez, M.; Acuña, J.D. \& Robles, F. 1981: Cova de les Cendres (Teulada, Alicante). Informe preliminar. Revista del Instituto de Estudios Alicantinos 34: 87-111.

LuIK, H. 2011: Material, Technology and Meaning: Antler Artefacts and Antler Working on the Eastern Shore of the Baltic Sea in the Late Bronze Age. Estonian Journal of Archaeology 15(1): 32-55.

LuIK, H. \& MAALDRE, L. 2007: Bronze Age bone artefacts from Narkûnai, Nevieriokë and Kereliai fortified settlements. Raw materials and manufacturing technology. Archeologia Lituana 8: 5-39.

Maggi, R.; Starnini, E. \& Voytek, B. 1997: The bone tools from Arene Candide: Bernabo Brea excavations. - Arene Candide: a Functional and Environmental Assessment of the Holocene Sequence (Excavations Bernabo Brea-Cardini 1940-50): 513-559. Éd. Il Calamo, Rome.

Marti Oliver, B. 1983: Cova de 1'Or (Beniarrés, Alicante). Memorias de las campañas de excavación 1975-1979. Noticiario Arqueológico Hispánico 16: $11-55$.

MăRgăRIt, M.; BĂLășESCU, A. \& Mirea, P. 2014a: Prelucrarea oaselor de ovi-caprine în nivelul Starčevo-Criş I din aşezarea de la Măgura 'Buduiasca' ('Boldul lui Moş Ivănuş') (Processing of Ovis aries/Capra hircus bones from the Starčevo-Criş I level at Măgura 'Buduiasca' ('Boldul lui Moş Ivănuş') settlement). Buletinul Muzeului Județean Teleorman. Seria Arheologie 6: 7-18.

MĂrgărit, M.; Boroneanț, A. \& Bonsall, C. 2017: Analiza morfologică și funcțională a pieselor din materii dure animale din situl mezolitic de la Ostrovul Banului (jud. Mehedinți) (Morphological and functional analyze of animal hard substances finds from Ostrovul Banului Mesolithic site (Mehedinți County)). Banatica 27: 39-72.

- in press: Exploatarea tehnologică a cornului în situl arheologic de la Ostrovul Corbului (Technological exploitation of Cervus elaphus antler at the Mesolithic site of Ostrovul Corbului). Banatica 28.

MĂrgărit, M.; Ștefan, C.E. \& Dumitrașcu, V. 2014b: Management of osseous materials for processing artifacts in the Boian settlement of Radovanu - La Muscalu (Romania). Archaeologia Bulgarica 18(3): 1-34.

MăRgăRIT, M. \& BoroneanȚ, A. 2017: Industria materiilor dure animale din situl mezolitic de la Alibeg (jud. Caraş-Severin) (The bone, antler and tusk assemblage from the Mesolithic site at Alibeg (Caraș-Severin County). Materiale și Cercetări Arheologice (serie nouă) XIII: 15-30.

MĂrgărit, M.; Boroneanț, A. \& Bonsall, C. in press: Analiza morfologică și funcțională a pieselor din materii dure animale din situl mezolitic de la Ostrovul Banului (jud. Mehedinți) (Morphological and functional analysis of materils made of hard animal materials from the Mesolithic site of Ostrovul Banului (Mehedinţi county). Banatica 27. 
Mıcu, C. 2004: Observaţii privind industria materiilor dure animale în aşezarea neolitică de la Isaccea, punctul "Suhat" (Observations on the hard animal materials industry from the Neolithic settlement of Isaccea, "Suhat" point). In: Cândea, I.; Sârbu, V. \& Neagu, M. (eds.): Prinos lui Petre Diaconu la 80 de ani: 41-75. Istros, Brăila-Călărași.

Mirea, P. 2005: Consideraţii asupra locuirii Starčevo-Criş din sud-vestul Munteniei (Considerations about the Starčevo-Criş cultural level in the southwest of Muntenia). In Honorem Silvia Marinescu-Bîlcu. CCDJ XXII: 37-52.

- 2011: Between Everyday and Ritual Use - 'Small Altars' or 'Cult Tables' from Măgura 'Buduiasca', Teleorman County (I): the Early Neolithic Finds". BMJT 3: 41-57.

Murray, C. 1979: Les techniques de débitage de métapodes de petits ruminants à Auvernier-Port. In: Camps-Fabrer, H. (ed.): Industrie de l'os et bois de cervidé durant le néolithique et âge des métaux. Première réunion du groupe de travail no. 3 sur l'industrie de l'os préhistorique: 27-35. Centre National de la Recherche Scientifique (CNRS). Paris.

Pascual Benito, J.L. 1996: Los anillos neolíticos de la Península Ibérica. I Congrés del Neolitic a la Peninsula Ibérica (Gavà-Bellaterra, 1995) 1: 279-289.

- 2016: Unas técnicas muy neolíticas: ranurado y abrasión para la elaboración de punzones a partir de metapodios de ungulados. Del neolític a l'edat del bronze en el Mediterrani occidental. Estudis en homenatge a Bernat Martí Oliver. TV SIP 119: 147-158.

PerLÈs, C. 2010: Grèce et Balkans: deux voies de pénétration distinctes du Néolithique en Europe ? In: Demoule, J.-P. (dir.): La révolution néolithique dans le monde: 263-281. CNRS Éditions, Paris.

Poplin, F. 1974: Deux cas particuliers de débitage par usure. $1^{e r}$ Colloque international sur l'industrie de l'os dans la Préhistoire: 85-92. Abbaye de Sénanque.

Roux, V. 2010: Technological innovations and developmental trajectories: Social factors as evolutionary forces. In: O'Brien, M.J. \& Shennan, S.J. (eds.): Innovation in cultural systems. Contributions from Evolutionary Anthropology: 217-234. The MIT Press, Cambridge.

- 2013: Spreading of Innovative Technical Traits and Cumulative Technical Evolution: Continuity or Discontinuity? Journal of Archaeological Method and Theory 20: 312-330.

SÉNÉPART, I. 1984: Premier aperçu sur l'industrie osseuse du Cardial (Espagne, Languedoc, Provence, Italie). Mémoire de DEA de l'Université d'Aix-en-Provence, Aix-en-Provence.
- 2004: Fiche travail l'os au Néolithique et du Chalcolithique dans le sud de la France. In: Ramseyer, D. (dir.): Cahier 11: Matières et techniques: 151-163. Éditions de la société préhistorique française, Paris.

SidÉRA, I. 1995: L'habitat du Rubané récent du Bassin parisien: L'industrie en matières osseuses. In: Ilett, M. \& Plateaux, M. (dir.): Le site néolithique de Berryau-Bac 'le Chemin de la Pêcherie' (Aisne): 116-125. C.N.R.S. éditions (Monographies du Centre de Recherches Archéologiques, 15). Paris.

- 2000a: Les Matières dures animales. L'outillage en os et en ivoire. In: Ramseyer, D. (ed.): Muntelier/ Fischergässli. Un habitat néolithique au bord du lac de Morat (3895 à 3820 avant, J.-C.): 118-156. Cahiers d'Archéologie fribourgeoise 15. Éd. Universitaires, Fribourg.

- 2000b: Animaux domestiques, bêtes sauvages et objets en matières animales du Rubané au Michelsberg. De l'économie aux symboles, des techniques à la culture. Gallia Préhistoire 42: 108-194.

- 2004: Exploitation de l'os au Néolithique dans les bassins parisien et rhénan. In: Ramseyer, D. (dir.): Cahier 11: Matières et techniques: 163-171. Éditions de la Société Préhistorique Française, Paris.

- 2005: Technical data, typological data: a confrontation. From Hooves to horns, from mollusc to mammoth. Manufacture and use of bone artifacts from Prehistoric Times to the Present. Proceedings of the $4^{\text {th }}$ Meeting of the (ICAZ) Worked Bone Research Group, Tallinn (Estonie), 26-31 août 2003: 81-90. Muinasaja Teadus 15.

- 2008: Rubané, VSG et Cardial. Filiations de l'industrie osseuse. In: Burnez-Lanotte, L.; Allard, P. \& Ilett, M. (eds.): Fin des traditions danubiennes dans le Néolithique du Bassin parisien et la Belgique (51004700 BC). Autour des recherches de Claude Constantin: 209-219. Mémoire 44 de la Société Préhistorique Française, Paris.

- 2012: Nouveau regard sur la néolithisation. L'industrie osseuse de l'Anatolie au Bassin parisien via la Méditerranée. De Boccard, Paris.

Stark, M.; Bowser, B. \& Horne, L. (eds.): 2008: Cultural transmission and material culture. Breaking down boundaries. Arizona University Press, Tucson.

Thissen, L. 2012: Starčevo-Criş pottery from TELEOR 003, S Romania. BMJT 4: 5-45.

- 2013: Middle Neolithic ceramics from TELEOR 003, Southern Romania. BMJT 5: 25-123.

Vitezović, S. 2013a: Bone industry from Starčevo-Grad. Technology and Typology. In: Lang, F. (ed.): The Sound of Bones. Proceedings of the $8^{\text {th }}$ Meeting of the ICAZ Worked Bone Research Group in Salzburg 
2011, ARCHEOPlus (Schriften zur Archäologie und Archäometrie an der Paris, Lodron, Band 5): 263276. Salzburg Universität, Salzburg.

- 2013b: The prehistoric bone tool assemblage from Grivac (Central Serbia). Journal of Serbian Archaeological Society 29: 209-232.

VoINEA, V.; GrigoruȚă, O. \& CĂRPUȘ, C. 2014: Hard animal material adornments discovered in Hamangia settlement from Gheia/Podoabe din materii dure animale descoperite în aşezarea Hamangia de la Cheia. In: Mărgărit, M.; Le Dosseur, G. \& Averbouh, A. (eds.): An overview of the exploitation of hard animal materials during the Neolithic and Chalcolithic/O privire asupra exploatării materiilor dure animale de-a lun- gul neoliticului și calcoliticului: 101-136. Cetatea de Scaun, Târgoviște.

Walker, A. \& BogaArd, A. 2011: Preliminary archaeological rezults from Teleor 003/Măgura Buduiasca. In: Mills, S. \& Mirea, P. (eds.): The Lower Danube in Prehistory: Landscape Changes and Human Environment Interactions - Proceedings of the International Conference, Alexandria 3-5 November 2010: 151-159. Renaissance, Bucureşti.

Woвst, H.M. 1999: Style in archaeology or archaeologists in style. In: Chilton, E.S. (ed.): Material Meanings: Critical Approaches to the Interpretation of Material Culture: 118-132. University of Utah Press, Salt Lake City. 
